Araştırma Makalesi

\title{
İstanbul Büyükşehir Belediye Başkanlığı Seçimi'nde Adayların Twitter İçeriklerinin Siyasal İletişim Açısından İncelenmesi
}

\author{
Fatih Çelik (Öğr. Gör. Dr.) \\ Trabzon Üniversitesi Vakfıkebir Meslek Yüksekokulu \\ fatihcelik@trabzon.edu.tr \\ ORCID: 0000-0002-3765-5284
}

Başvuru Tarihi: 15.08.2019

Yayına Kabul Tarihi: 04.11.2019

Yayınlanma Tarihi: 24.01.2020

DOI: http://10.17680/erciyesiletisim.605538

\section{Öz}

Gelişen iletişim teknolojileri ile birlikte tüm disiplinlerde olduğu gibi siyasal iletişim disiplini de bir değişim ve dönüşüm içerisine girmiştir. Partilerin ve politikacıların siyasal iletişim çalışmalarını dijital ortama taşıması ve bu ortamda hedef kitle olan seçmelerle doğrudan iletişim kurulması incelenmesi gereken birçok konuyu da beraberinde getirmektedir. Söz konusu bu çalışma, Yüksek Seçim Kurulu (YSK) tarafından tekrarlanan 23 Haziran 2019 İstanbul Büyükşehir Belediye (IBB) Başkanlığı seçiminde Cumhur İttifakı Adalet ve Kalkınma Partisi (AK Parti) adayı Binali Yıldırım ve Millet İttifakı Cumhuriyet Halk Partisi (CHP) adayı Ekrem İmamoğlu'nun Twitter içeriklerini siyasal iletişim açısından analiz etmeyi amaçlamaktadır. Seçim kampanyası dönemine denk gelen 9 Mayıs-22 Haziran 2019 tarihleri arasında adayların resmi Twitter hesaplarından paylaştıkları içerikler Maxqda nitel veri analizi programı ile toplanmış ve içerik analizi tekniğiyle incelenerek analiz edilmiştir. Araştırmada tweet'ler; konum ve etkinlik, seçim kampanyası iletişimi, kişisel mesaj, bilgi ve açıklama, kişilerarası diyalog, seçilmiş ve atanmışlarla iletişim ve diğer/bilinmeyen olmak üzere toplam yedi kategori olarak sınıflandırılmıştır. Ayrıca araştırmada, adaylar tarafından en sık kullanılan hashtag'ler tespit edilmiş, hashtag'ler ile tweet kategorileri arasındaki ilişkiye bakılmış ve adayların kelime sıklık çözümlemeleri gerçekleştirilmiştir. Sonuç olarak, adayların Twitter’ı daha çok konum ve etkinlik, seçim kampanyası iletişimi, kişisel mesaj ile bilgi ve açıklama için kullandıkları söylenebilir. Ayrıca çalışmada, adayların sosyal medyanın en önemli getirilerinden birisi olan etkileşim özelliğini fazla önemsemedikleri ortaya çıkmıştır.

Anahtar Kelimeler: Siyasal İletişim, Twitter, 23 Haziran İstanbul Büyükșehir Belediye Başkanlığı Seçimi, Binali Yıldırım, Ekrem İmamoğlu. 
Research Article

\title{
Investigation of the Twitter Content of the Candidates from the Perspective of Political Communication in Istanbul Metropolitan Mayoralty Elections
}

\author{
Fatih Çelik (Lect. Ph.D.) \\ Trabzon University Vakfıkebir Vocational School \\ fatihcelik@trabzon.edu.tr \\ ORCID: 0000-0002-3765-5284
}

Date Received: 15.08 .2019

Date Accepted: 04.11.2019

Date Published: 24.01.2020

DOI: http://10.17680/erciyesiletisim.605538

\begin{abstract}
As with all disciplines, political communication discipline has entered into a change and transformation with the developing communication technologies. The fact that parties and politicians carry their political communication to the digital environment and direct communication with the target group auditions in this environment brings many issues that need to be examined. This study aims to analyze Twitter contents of repeated by the Supreme Election Board (SEB) on June 23, 2019 Istanbul Metropolitan Mayoralty (IMM) Public Alliance Justice and Development Party (JDP) candidate Binali Yıldırım and the National Alliance Republican People's Party (RPP) candidate Ekrem İmamoğlu. The content that the candidates shared on their official Twitter accounts between 9 May-22 June 2019 during the election campaign period was collected through Maxqda qualitative data analysis program and analyzed and examined by content analysis technique. Tweets in the research was classified by location and activity, election campaign communication, personal message, information and explanation, interpersonal dialogue, communication with selected and appointed persons, and other/unknown categories. In addition, the most frequently used hashtags were determined by the candidates, the relationship between hashtags and tweet categories was examined and the word frequency analyzes of the candidates were done. As a result, it can be said that candidates use Twitter more for location and activity, election campaign communication, personal message and information and explanation. In the study, it was revealed that the candidates did not much attention to the interaction feature which is one of the most important benefits of social media.
\end{abstract}

Keywords: Political Communication, Twitter, June 23 Istanbul Metropolitan Mayoralty Election, Binali Yıldırım, Ekrem İmamoğlu. 


\section{Giriş}

Son yıllarda sosyal medya, bireylerin yanı sıra kurum, kuruluş ve organizasyonları da derinden etkileyen bir ortam haline gelmiștir. Tüm dünyayı adeta 'kasıp kavuran' bu yeni ortam insanlar tarafından yoğun bir şekilde kullanılmaktadır. 7.7 milyarlık dünya nüfusunun yaklaşık olarak \%56'sının (4.3 milyar) internet kullanıcısı olduğu bu dijital ortamda, yaklaşık 3.5 milyar kişi ise, aktif sosyal medya kullanıcısıdır. Bu sayı dünya nüfusunun yaklaşık \%46'sına denk gelmektedir (Kemp, 2019a). Türkiye'de ise, 82.4 milyonluk nüfusun 59.3 milyonu internet kullanırken, 52 milyon kişi aktif olarak sosyal medya platformlarını kullanmaktadırlar (Kemp, 2019b). Hem dünya üzerinde hem de Türkiye'de insanlar interneti daha çok sosyal medya platformlarında zaman geçirmek için tercih etmektedirler. Öte yandan kavram olarak sosyal medya, elektronik metinlerin, grafiklerin, videoların, hareketli görüntülerin ve sesin kombinasyonlarını içeren ve insanların uygun amaçları için verilerle etkileşime girmelerini sağlayan dijital ortamın yapılandırılmış bir bilgisayarlı ortama entegre edilme sürecidir (Njoroge, 2013, s. 8).

Sosyal medyayı da içine alan yeni medyanın ortaya çıkışı ile birlikte 'dijital iletişim', 'sanal iletişim', 'çevrimiçi iletişim' veya 'online iletişim' gibi kavramlar artık sıklıkla kullanılmaya başlanmıştır. Dijital iletişim, iletişim faaliyetlerinin sosyal ağ ve internet gibi dijital ortamlarda yürütülmesidir. Web sitesi, Instagram, YouTube, Facebook ve Twitter bugün etkili dijital iletişim ortamlarıdır ve kitlesellik, hız ve etkileşim bağlamında artık insanlar tarafından sıklıkla tercih edilmektedir. Dijitalleşme ile birer içerik üreticisi haline gelen insanlar, büyük ölçüde sosyal ağlarda gezinmekte; siyasal, kültürel, toplumsal birçok alanda düșüncelerini paylaşmakta ve diğer kullanıcıları takip etmektedirler (Güz vd., 2019, s. 1467). Dijitalleşme ile beraber, birey, kurum veya markaların yanı sıra, siyasal alan içerisinde yer alan partiler, siyasetçiler ve seçmenler de doğrudan etkilenmiş ve siyasal iletişim kampanyaları dijital ortama taşınmaya başlanmıştır.

Siyaset basitçe, toplumda yer alan bireyleri etkileme ve yönetme çabası olarak tanımlanmaktadır. Siyasal aktörler toplum ile sürekli iletişim halinde olmak zorundadırlar. $\mathrm{Bu}$ iletişim kurma çabasının arkasında egemenlik, iktidar, yönetme, manipüle etme gibi kavramlar olduğu için bu süreç siyasal iletişim süreci olarak değerlendirilmektedir (Kılıçaslan ve Çalışır, 2018, s. 471). Siyasal iletişim, siyasal aktörlerin belli ideolojik amaçlarını ve politikalarını belli gruplara, kitlelere, ülkelere ya da bloklara kabul ettirmek ve gerektiğinde eyleme dönüştürmek ve uygulamaya koymak üzere çeşitli iletişim tür ve tekniklerinin kullanılma sürecidir (Aziz, 2015, s. 3-4).

Bilgi ve iletişim teknolojilerindeki gelişmeler doğrultusunda kitle iletişim araçları da değişime uğramıștır. Televizyon, radyo, gazete, dergi gibi araçların yerini artık hepsini 'tek bir çatı' altında toplayabilen internet almaya başlamıştır. Yeni 'bacasız endüstri' olarak da tanımlanabilen ve her kesim tarafından etkin bir şekilde kullanılan internet ve sosyal medya, gündem belirleme ve kitleleri doğrudan etkileme özelliğinden dolayı ürün ya da hizmet üreten kurum, kuruluş ve markaların yanı sıra, siyasal örgütler için de önemli bir teknolojik araç haline gelmiştir (Çelik ve Aktaş, 2017, s. 458). Özellikle internetin çağımızda gittikçe yaygınlık kazanması ve sosyal medya platformlarının kitleleri etkileyici bir şekilde devreye girmesiyle 'dijital siyaset' veya 'çevrimiçi siyaset' dönemi başlamıştır. İnteraktif olan bu dijital siyaset, siyasal iletişim alanında geleneksel medya ve eski tarz siyaset yapma alışkanlıklarını ciddi anlamda etkilemiş (Genel, 2012, s. 23) ve karar vericiler tarafından bu gelişmeler doğrultusunda yeni kararlar alınmaya başlanmıştır. Örneğin, AK Parti Genel Başkanı ve Cumhurbaşkanı Recep Tayyip Erdoğan, geleneksel alışkanlıklar olan ve görüntü kirliliğine yol açan parti bayrakları ve 
afişlerini, 31 Mart 2019 yerel seçimler sürecinde yürütecek olan seçim kampanyasında kullanmayacaklarını ve dijital alana daha çok önem vereceklerini söylemiştir (CNN Türk, 2018). Parti veya adayların seçim çalışmaları, teknolojinin yardımı, internetin sağladı̆̆ı firsatlar ve sosyal medyanın geniş kitlelere ulaşabilme kabiliyeti ile birlikte dijital ortama hızla taşınarak yeni seçim stratejilerinin ortaya çıktığı mecralar oluşmaya başlamıştır (Örselli vd., 2018, s. 696).

Sosyal medya platformları içerisinde özellikle parti ve siyasetçiler tarafından en sık kullanılan platformların başında Twitter gelmektedir. Dünyanın en popüler mikroblog sitesi olan Twitter, kullanıcıların herhangi bir konu hakkındaki düşüncelerini takipçileri ile paylaşmasını sağlayan ücretsiz bir çevrimiçi hizmettir. Söz konusu düşünceleri içeren kısa mesajlar 'tweet' olarak adlandırılmaktadır. Facebook ve MySpace gibi diğer sosyal paylaşım sitelerinin aksine, bir hesabın takipçisi olmak için, eğer profil gizlenmemiş ise, izin ya da karşılık gerektirmez. Twitter'ı karakterize eden iki özellik ise, "neler oluyor?" sorusu ve 280 veya daha az karakterden oluşan kısa mesajlardır (İkiz vd., 2014, s. 42). Kemp (2019b)'e göre, dünyada en çok kullanılan sosyal ağlar sıralamasında Twitter, 2019 Haziran ayı itibariyle 330 milyon kullanıcısı sayısı ile sekizinci sırada yer almaktadır. Türkiye'de ise, 9 milyon kullanıcısı sayısı ile en sık kullanılan dördüncü sosyal medya platformudur (Kemp, 2019a). İnsanların Twitter kullanmasının en temel amacı ise, bilgi paylaşmak ve diğer insanlarla iletişim halinde olmaktır (İkiz vd., 2014, s. 42). Twitter, farklı görüşlerin ve sağlıklı bir demokratik kültürü teşvik eden çeşitli seslerin ortaya çıkarılmasıyla aşağıdan yukarıya bir güç müzakere aracı haline gelmiştir (Ifukor, 2010, s. 401-402).

Twitter'ın çoğunlukla toplumsal veya politik olaylar sürecinde hedef kitleye erişmek ve onlarla ilişki ve iletişim kurmak için kullanıldığından dolayı siyasal iletişimin temel araçlarından birisi olarak görülmektedir (İkiz vd., 2014, s. 41). Twtitter'ın iki yönlü iletişime imkân tanıyan yapısı gibi, kitlesellik özelliği ve günden güne popüler olması da siyasi aktörlerin ilgili platformu, siyasal iletişim çabaları içerisinde yer alan dijital seçim kampanyası aracı olarak seçmesinde etkili olmuştur (Güz vd., 2019, s. 1476). Özellikle 2008 yılında ABD'de gerçekleşen başkanlık seçiminde Barack Obama'nın seçimi kazanmasının en temel nedenlerinden bir tanesi de seçim kampanyası sürecinde başta Twitter olmak üzere sosyal medyayı etkili bir şekilde kullanmasıdır. Obama'nın "Yes, We Can (Evet, Yapabiliriz)" sloganın merkezde olduğu kampanya süreci, birçok ülkede politikacılara örnek teşkil etmektedir (Tongut ve Akman, 2014, s. 121). Obama, Beyaz Saray’a yönelik önemli bilgileri yaymak için Twitter'ı özellikle kullanmıştır. Öte yandan 2010 Birleşik Krallık genel seçimlerinde; sitenin yalın ve sade olması ile yayın kolaylığı gibi temel tasarım özellikleri, bireysel düşünceleri ve tepkileri gerçek zamanlı olarak paylaşmaya olanak sağlaması, çoğu içeriğin kamu malı olması ile ilgili olarak nispeten açık bir platform olması ve sitenin yapısının verileri ticari olarak kolayca elde edebilmek için oluşturulmuş olması gibi nedenlerden dolayı kamuoyunu ölçmek isteyenler için en yararlı kaynak Twitter olmuştur (Anstead ve O’Loughlin, 2012, s. 4).

Türk siyasi tarihinde sosyal medyanın kullanımı incelendiğinde, ilk olarak 2009 yerel seçimlerinde sosyal medyaya yönelik çabalar ortaya çıkmıştır. 2009 yerel seçimlerinde, siyasi partilerin gençlik kollarının yoğun bir şekilde faaliyetlerini ve parti politikalarını kamuoyunu duyurmak amacıyla Facebook gibi sosyal ağları kullandıkları ve bazı belediye başkan adaylarının kendi Facebook hesaplarından seçmenlerine hitap etmeyi tercih etmişlerdir. Twitter ise, 2009 yılından itibaren Türkiye'de yaygınlaşmış ve özellikle 2011 
yılı genel seçimler ve 2014 yılı yerel seçimlerinde parti, lider ve adaylar tarafından sık bir şekilde kullanılmaya başlanmıştır (Bayraktutan vd., 2014, s. 167).

Günümüzde siyasetçiler, partiler veya adaylar resmi Twitter hesaplarından içerikler paylaşarak dijital kampanyalarını takipçileri ve kamuoyuna aktarmaktadırlar (Örselli vd., 2018, s. 709). Bu aktarım sürecinde hashtag, mention ve retweet gibi sosyal medyanın özelliklerinden yararlanılması yeni bir politik iletişim şeklinin ortaya çıkmasına neden olmuştur (Sukmayadi vd., 2018, s. 247). Siyasetçilerin, hedef kitleye yönelik bilgi akışlarında etkileşimi yönetmek için bu özellikleri sıklıkla kullanması kampanyanın güçlenmesi sağlamaktadır (Conover vd., 2011, s. 89). Bu kullanım özelliklerinin başında gelen hashtag'ler (\#), içeriğin hızlı bir şekilde yayılmasını ve daha çok kişiye erișmesini sağlamaktadır (Bayraktutan vd., 2012, s. 16). Siyasi parti ve adaylar tarafından hashtag'ler sıklıkla kullanılarak daha çok seçmene erişim sağlanmakta ve aktarılmak istenilen mesaj kolay bir şekilde kitlelere ulaştırılmaktadır. Bunun yanı sıra kullanıcılar veya siyasetçiler, diğer hesaplar tarafından paylaşılan içerikleri direkt retweet ederek veya kendi düşüncelerini yazarak paylaştıkları alıntılama türü retweet'leri kullanarak etkileșime katkıda bulunabilmektedirler. Twitter'ın bir diğer özellik olan mention (@) ise, kullanıcının diğer hesapları etiketleyerek içerik paylaşımı yapmasıdır. Siyasetçiler veya partiler bu özelliği kullanarak takipçileri ile etkileşim süreci başlatabilmekte veya kendilerine yönelik bu tür içeriklere cevap verebilmektedirler. Son olarak URL ise, kullanıcıların herhangi bir web sitesi veya belirli bir sosyal medya hesabına yönlendirme yapmak için hesabında web sitesinin adresini paylaşmasıdır. Bu şekilde siyasetçiler veya partiler hem daha geniş içerikleri hedef kitleleri ile buluşturabilmekte hem söz konusu web sitesinin trafiği artırılabilmekte hem de kullanıcıların siyasetçi veya parti ile ilgili içeriklerle daha fazla zaman geçirebilmesi sağlayabilmektedir.

Literatürde siyaset ve sosyal medya ilişkisi konusunda yaplan birçok çalışma web 2.0 uygulamalarının vatandaşlara siyasal olarak daha katılımcı olma fırsatını tanıdığını ileri sürmektedir (Örselli vd., 2018, s. 701). Sobaci ve Karkin (2013, s. 419)'a göre, literatürdeki araștırmalarda vurgulanan ortak bulgu, Twitter bașta olmak üzere sosyal medya platformlarının kullanımının gün geçtikçe artması ve siyasi iletişimin ve kampanyaların doğası üzerinde derin bir etkiye sahip olmasıdır. Diğer taraftan literatürde, genel seçim (Ahmed vd., 2016; Çelik ve Aktaş, 2017; Güdekli, 2016; Larsoon ve Ihlen, 2015; Silsüpür, 2016; Stier vd., 2018; Vergeer ve Hermans, 2013), devlet başkanlığı seçimleri (Adams ve McCorkindale, 2013; Bossetta, 2018; Christensen, 2013; Doğan ve Ertan, 2016), referandum (Budak, 2018; Emiroğlu, 2019; Demirhan, 2017; Kılıçaslan ve Çalışır, 2018; Örselli vd., 2018) ve yerel seçimler (İkiz vd., 2014; Larsson, 2018; Sobaci ve Karkin, 2013; Triantafillidou vd.,2018; Tongut ve Akman, 2014) gibi alanlarda önemli çalışmalar söz konusudur. Bu çalıșmalar daha çok parti, lider veya adayların sosyal medya veya Twitter kullanım pratiklerine odaklanmaktadır. Söz konusu bu araștırmalarda en sık kullanılan yöntem, paylaşımların belirli kategorilere göre değerlendirildiği içerik analizi yöntemidir (Adams ve McCorkindale, 2013; Ahmed vd., 2016; Budak, 2018; Çelik ve Aktaş, 2017; Demirhan, 2017; Emiroğlu, 2019; Marques ve Mont'Alverne, 2016; Örselli vd., 2018; Ramos-Serrano vd., 2018; Silsüpür, 2016; Sobaci ve Karkin, 2013; Sukmayadi vd., 2019.

Literatürdeki araştırmalardan yola çıkarak politikacıların genel olarak Twitter'ı; bilgilendirme, etkileşim, harekete geçirme, haber, eleştiri, övgü, vaat, ülke ve dünya gündemi, etkinlik duyurumu, seçim kampanyası iletişimi, propaganda, kutlama/ tebrik, kişisel mesaj paylaşımı gibi amaçlar doğrultusunda kullandıkları söylenebilir (Bayraktutan vd., 2014; Çelik ve Aktaş, 2017; Doğan ve Ertan, 2016; Honeycutt ve Herring, 
2009; Lilleker vd., 2011; Örselli vd., 2018; Sukmayadi vd., 2019; Tongut ve Akman, 2014). Ayrıca politikacılar; başarılı olmak, kendi amaçlarını belirlemek, sorumluluk sahibi olmak, zenginlik, dürüstlük, özgürlük, ulusal güvenlik ve sosyal güç gibi söylemleri Twitter'da öne çıkartabilmektedir (Yllmaz ve Karakaş, 2019). Öte yandan dijital siyasette iktidar partisi ve yakınında yer alanlar daha çok pozitif bir kampanya yürütürken, muhalefet partileri daha çok negatif bir kampanya yürütmeyi tercih edebilmektedir (Kılıçaslan ve Çalışır, 2018).

Yoğun internet ve sosyal medya kullanımı ile beraber seçim kampanyaları ile ilgili çevrimiçi ortamlar için yüksek beklentiler söz konusudur ve özellikle büyükşehir gibi nüfusun yoğun olduğu bölgelerdeki seçmenlere ulaşma konusunda Twitter daha cazip bir platform olarak değerlendirilmektedir (Gullati ve Williams, 2007, s. 446). Vatandaşlarla iletişim kurmak için yerel politikacılar tarafından son dönemlerde yoğun bir şekilde kullanılan Twitter, kişisel, doğrudan, etkileșimli ve hızlı bir platform olması nedeniyle yerel düzeyde çevrimiçi siyasal iletişim için uygun bir araç olarak düşünülmektedir (Criado vd., 2012, s. 222; Triantafillidou vd., 2018, s. 66). Yerel politikacllar seçmenleriyle daha kişisel ve daha az parti odaklı bir şekilde iletişim kurmanın ve genç seçmenleri kendi lehine çekmeye çalışmanın önemini anlamaya başlamışlardır (Triantafillidou vd., 2018, s. 67). Yerel seçimlerde adayların Twitter kullanım amacı diğer politikacılara göre biraz farklılaşabilmektedir. Özellikle kamu hizmeti projeleri, vatandaşlarla doğrudan iletişim kurma, atanmış ve seçilmişlerle iletişim ve kendini tanıtma gibi faktörler yerelde Twitter kullanım amacı olarak ortaya çıkabilmektedir (İkiz vd., 2014; Sobaci ve Karkin, 2013; Triantafillidou vd., 2018).

Tüm bunlar beraber değerlendirildiğinde, söz konusu bu çalışma, YSK'nın büyük tartışmalara yol açan 31 Mart 2019 İBB Başkanlık seçimlerini iptal etmesi sonucunda, ilk seçimin kazananı Millet İttifakı CHP adayı Ekrem İmamoğlu ile Cumhur İttifakı AK Parti adayı Binali Ylldırım'ın, siyasal iletişim bağlamında resmi Twitter hesaplarından seçim kampanyası sürecinde paylaşılan içeriklerin nasıl olduğunun incelenmesi ve analiz edilmesidir. Bu araştırma konusundan hareketle çalışmanın bundan sonraki bölümlerinde, araştırmanın amacı, önemi, literatüre katkısı, yöntemi, örneklemi, veri toplama aracı, araştırma soruları, analizi, bulguları, tartışma ve sonucuna yer verilmektedir.

\section{Yöntem}

Bu çalışmanın amacı, YSK tarafından tekrarlanan 23 Haziran 2019 İBB Başkanlığı seçiminde Cumhur İttifakı AK Parti adayı Binali Yıldırım ve Millet İttifakı CHP adayı Ekrem İmamoğlu'nun Twitter paylaşımlarının siyasal iletişim açısından incelenmesidir. Bilgi ve iletişim teknolojilerindeki gelişmeler doğrultusunda siyasal iletişim faaliyetleri farklı boyutlara evrilmiştir. Geleneksel seçim kampanyaları günden güne dijital seçim kampanyalarına dönüşmeye başlayan bu süreçte hem partiler hem de politikacılar adına hiç kuşkusuz Twitter önemli bir etken haline gelmiştir. Bu noktadan hareketle, Türkiye'de her geçen gün artan Twitter kullanıcı sayısından dolayı siyasi partilerin ve politikacıların Twitter kullanımlarının siyasal iletişim açısından analiz edilmesi ve rakipleri ile meydanlarda girdikleri mücadelenin çevrimiçi ortamlarda nasıl sürdürüldüğünün ortaya çıkarılması önemlidir. Ayrıca siyasal iletişim sürecinde, Twitter'ın yerinin ve öneminin ortaya konulması önem arz etmektedir. Diğer taraftan hem yerli hem de yabancı literatürde genel seçimler ve devlet başkanlığı seçimlerinde parti ve adayların Twitter kullanımlarıyla ilgili çalışmalar oldukça fazladır. Fakat yerel seçimlerle ilgili özellikle yerli literatürde bazı eksiklikler söz konusudur ve diğer seçim türlerine göre daha 'kıyıdaköşede' yer almaktadır. Bu nedenle çalışmanın İstanbul gibi bir dünya kentinin belediye 
başkanı seçimi ile Twitter arasındaki ilişkiyi derinlemesine inceleyecek olmasından dolayı literatüre önemli katkıda bulunacağı tahmin edilmektedir.

Çalışmada verileri değerlendirmek için nitel içerik analizi tekniği kullanılmıștır. İçerik analizi ve tweet kategorizasyonu siyasal iletişimde Twitter kullanımı literatüründe en çok kullanılan yöntemdir (Sobaci ve Karkin, 2013, s. 419). İçerik analizi, metinlerden veya diğer anlamlı verilerden, kullanım bağlamları doğrultusunda tekrarlanabilir ve geçerli çıkarımlar yapmak için belirli kategorilere içeriklerin yerleştirilmesi şeklinde kullanılan bir araştırma tekniğidir (Krippendorff, 2004, s. 18).

İçerik analizi, herhangi bir veride kullanılan her türlü karakterin niteliksel ve sayısal olarak analizini mümkün kılan bir tekniktir. Sayısallaştırma, içerik analizinde popüler bir kullanımdır. Nicel ve nitel yöntemlerin kullanıldığı içerik analizi tekniği, örneklem doğrultusunda verinin içeriğinden yola çıkmak koşuluyla, sezgisel olarak anlamlı benzerliklere dayanan çlkarımlar yapılmasını sağlamaktadır (Doğan ve Ertan, 2016, s. 144; Krippendorff, 2004, s. 210). Nitel içerik analizi sürecinde, nitel veriler sayısal verilere dönüştürülerek ölçülebilir hale getirilmekte ve bu sayede gerekli analizler yapılarak anlamlı sonuçlar elde edilmektedir (Fidan, 2015, s. 237). Ortaya çıkan verilerden bazı çıkarımlar yaparak, içerikte gözlenen veya betimlenen unsurlardan hareketle bir açılkama yapma amacına sahip olan nitel içerik analizi (Yılmaz ve Karakaş, 2019, s. 151), araştırmanın amacı doğrultusunda bu çalışmada kullanılmıştır.

İçerik analizi için veriler, 31 Mart 2019 İBB Başkanlığı seçimlerine ittifak olarak giren ve en yüksek oyu alan iki aday ve seçim kampanyasının en etkin dönemini oluşturan 9 Mayıs-22 Haziran 2019 tarihleri amaçlı örneklem yönetimiyle toplanmıştır. Cumhur İttifakı AK Parti adayı Binali Yıldırım’ın 27 Mayıs 2019 tarihine kadar “@TCMeclisBaskani” ve 27 Mayıs 2019 tarihinden sonra "@BY" isimli hesaplarından ve de Millet İttifakı CHP adayı Ekrem İmamoğlu’nun “@ekrem_imamoglu” hesabından paylaştıkları içerikler Maxqda nitel veri analizi programı ile toplanmış ve analiz edilmiştir. Binali Yıldırım bu süreçte Twitter hesabını değiştirmiş ve daha kişisel bir hesap kullanmaya başlamıştır.

\section{Veri Toplama Aracı ve Analiz}

İçerik analizi sürecinde kategoriler daha önce gerçekleştirilen çalışmalar doğrultusunda belirlenmiş ve Maxqda programı vasıtasıyla kodlamalar gerçekleştirilmiştir. Tweet kategorileri Çelik ve Aktaş (2017), Sobaci ve Karkin (2013) ve Van Dijck (2011)'in çalışmalarından esinlenerek oluşturulmuştur. Çalışmada, kodların istatistiği, karşılaştırma ve ilişki analizi ile kelime bulutu analizleri gerçekleștirilmiştir. Maxqda nitel analiz programında veriler öncelikle alt kodlar halinde kodlanmakta ve daha sonra bu kodlar kategoriler haline getirilerek analizler gerçekleştirilmektedir. Binali Yıldırım için 1847 ve Ekrem İmamoğlu için ise 1256 kodlama yapılmıştır. Toplam çalışmada 3103 kodlama yapılarak analizler için veriler hazır hale getirilmiştir.

\section{Araştırma Soruları}

1. Tekrar edilen İBB Başkanlığı seçiminde Cumhur İttifakı ve Millet İttifak adaylarının siyasal söylem ve etkinliklerinde Twitter kullanmanın rolü nedir?

2. Seçim öncesi kampanyanın 45 günlük sürecinde Twitter siyasal iletişim aracı olarak aktif bir şekilde adaylar tarafından kullanılmış mıdır?

3. Seçim öncesi son 45 günlük süreçte adayların Twitter'ın sunduğu imkânları (düz tweet, mention, retweet, alıntılama) kullanım oranları nelerdir? 
4. Tekrarlanan seçim öncesi son 45 günlük süreçte Cumhur İttifakı ve Millet İttifak adaylarının Twitter kullanım amaçları nelerdir?

5. Seçimler öncesinde adayların Twitter'da hashtag kullanım oranı nedir ve en sık kullandıkları hashtag'ler nelerdir?

6. Adaylar tarafından en sık kullanılan hashtag'ler ile Twitter kullanım amaçları arasında bir ilişki var mıdır? Eğer var ise, hangi hashtag ile kullanım amacı arasında ilişski söz konusudur?

7. Tekrarlanan seçim öncesi son 45 günlük süreçte Cumhur İttifakı ve Millet İttifak adaylarının resmi Twitter hesabından paylaştıkları tweet'lerin içeriğinde en sık kullanılan kelimeler nelerdir, adaylar bu kelimeleri hangi amaçlar için kullanmışlardır?

\section{Bulgular}

\section{Twitter İçerik Türlerinin Kullanımı ve Paylaşılan Tweet Sayısı}

09 Mayıs-22 Haziran 2019 tarihleri arasında Binali Yıldırım 518 düz tweet, 11 mention, 12 alıntılama paylaşıp 23 retweet yaparken, Ekrem İmamoğlu 354 düz tweet, 1 alıntılama paylaşmış ve 6 retweet yapmıștır. Ekrem İmamoğlu bu süre boyunca Twitter'ın cevaplama niteliğindeki mention özelliğini hiç kullanmamıștır. Araştırmada, Binali Yıldırım Ekrem İmamoğlu'na göre çok daha fazla diğer hesapların içeriklerini retweet yapmıştır. Fakat araștırmanın bundan sonraki evresinde, çalıșmanın sınırlılı̆̆ gereği retweet'ler analiz dışında tutulmuştur. Sonuç olarak, Binali Yıldırım'ın 541 ve Ekrem İmamoğlu'nun 355 olmak üzere toplam 896 tweet analiz edilmiştir (Tablo 1).

Tablo 1: Twitter İçerik Türlerinin Kullanımı

\begin{tabular}{|l|c|c|c|}
\hline Tweet Türü & Binali Yıldırım & Ekrem İmamoğlu & Toplam \\
\hline Düz Tweet & 518 & 354 & 872 \\
\hline Mention & 11 & - & 11 \\
\hline Alıntılama & 12 & 1 & 13 \\
\hline Retweet & 24 & 6 & 30 \\
\hline Toplam & 565 & 361 & 926 \\
\hline
\end{tabular}

Adayların 9 Mayıs-22 Haziran 2019 tarihleri arası resmi Twitter hesaplarından paylaşılan içeriklerin oranı günlük olarak incelendiğinde, Binali Yıldırım'ın toplam tweet sayısında olduğu gibi günlük paylaşım sayısında da önde olduğu görülmektedir. Ekrem İmamoğlu genellikle belli bir seviyede günlük tweet paylaşımı yaparken, Binali Yıldırım'ın tweet sayısında belli dönemlerde dalgalanmalar olduğu söylenebilir. Özellikle seçimin yapılacağı ay olan Haziran ayına giriş ile birlikte her iki adayında tweet sayılarında yükselme dikkat çekmektedir. Ayrıca seçim haftasına giriş ile birlikte, adayların tweet sayılarında önemli derecede bir artış söz konusudur. Diğer taraftan, Binali Yıldırım bu süre boyunca günlük ortalama 12 tweet paylaşırken, Ekrem İmamoğlu ise, günlük ortalama 8 tweet paylaşmıștır. Sonuç olarak, Cumhur İttifakı adayı Binali Yıldırım'ın seçim kampanyası döneminde Twitter'ı rakibine göre daha aktif kullandığı söylenebilir (Şekil 1). 


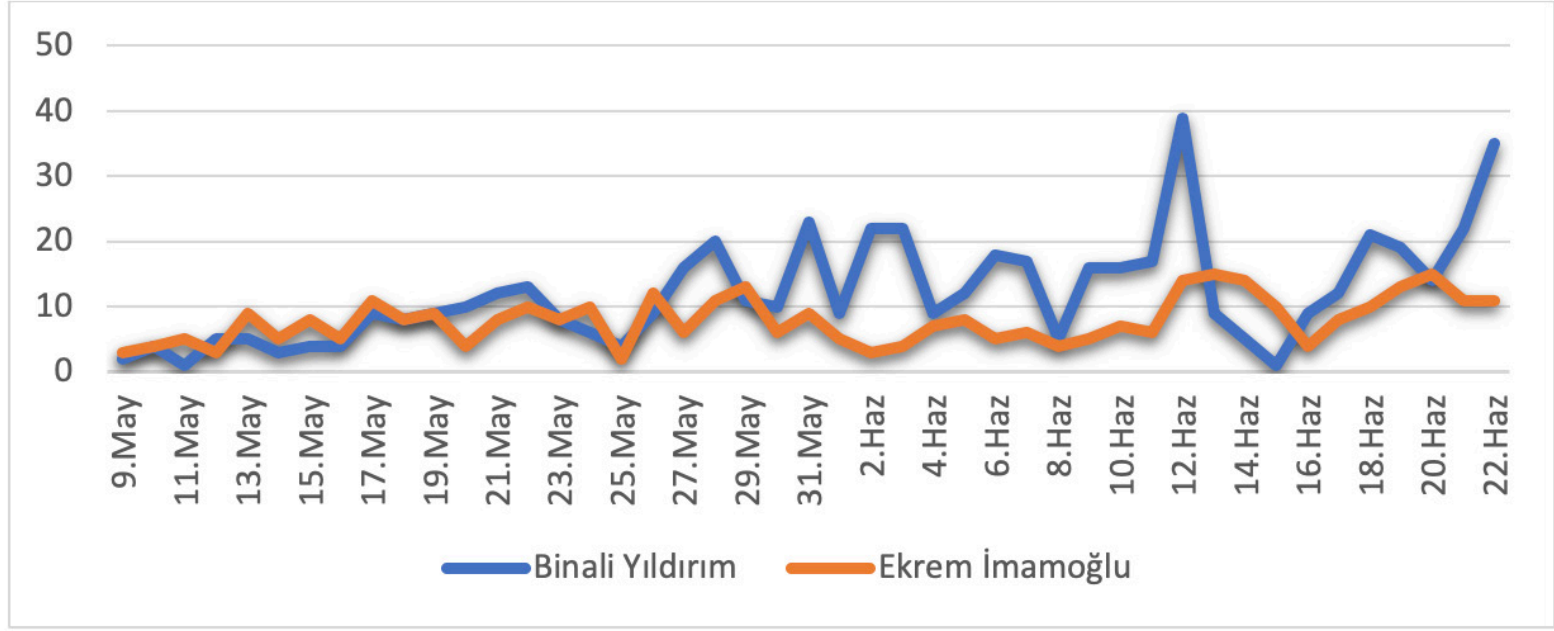

Şekil 1: Adayların Günlük Tweet Sayıları (9 Mayıs-22 Haziran)

\section{Tweet Kategorilerinin Kullanımı}

İçerik analizi çalışmalarında benzer kodların bir araya getirilmesi ile oluşturulan kategoriler çalışmaların amaçlarını ortaya çıkarmada önemli bir role sahiptir. Söz konusu bu araştırmada, adayların Twitter hesaplarından paylaştıkları içerikler toplam yedi kategori üzerinden değerlendirilmiștir (Tablo 2).

Tablo 2: Tweet Kategorileri ve Tanımları

\begin{tabular}{|c|c|}
\hline Tweet Kategorileri & Tanım \\
\hline Konum ve Etkinlik & $\begin{array}{l}\text { Miting, toplantı, açılış, ziyaret, konferans, buluşma gibi } \\
\text { etkinliklerin yanı sıra tv, radyo ve sosyal medya programları } \\
\text { ile ilgili içerikler bu kategoride değerlendirilmektedir. }\end{array}$ \\
\hline Seçim Kampanyası İletişimi & $\begin{array}{l}\text { Adayların gerçekleştirdiği icraatlar, vaatler, birbirlerine ve diğerlerine } \\
\text { yönelik eleştiriler gibi eylemler bu kategoride yer almaktadır. }\end{array}$ \\
\hline Kişisel Mesaj & $\begin{array}{l}\text { Adayın kendisi ile ilgili paylaşımlarının yanı sıra, özel gün ve olaylar, } \\
\text { gündemdeki konular, kutlamalar, anmalar, tebrikler, taziye dilekleri gibi } \\
\text { siyasal bir mesaj içermeyen toplumsal olaylara yönelik paylaşımlardır. }\end{array}$ \\
\hline Bilgi ve Açıklama & $\begin{array}{l}\text { Adayların hesapları üzerinden yapmış oldukları bilgilendirici } \\
\text { içerikler ve günlük gelişmelere yönelik yaptıkları açıklamalar } \\
\text { bu kategori içerisinde değerlendirilmiştir. }\end{array}$ \\
\hline Kişilerarası Diyalog & $\begin{array}{l}\text { Adayların diğer kullanıcılara mention şeklinde cevap vermesi ve cevap } \\
\text { niteliğindeki alıntılama türü paylaşımlar bu kategoride yer almaktadır. } \\
\text { Bu kategori, kullanıcılar arasındaki iki yönlü iletişimi göstermektedir. }\end{array}$ \\
\hline $\begin{array}{l}\text { Seçilmiş ve Atanmışlarla } \\
\text { İletişim }\end{array}$ & $\begin{array}{l}\text { Bu kategori Cumhurbaşkanı, Parti Genel Başkanı, Milletvekili, } \\
\text { Bakan, diğer Belediye Başkanları gibi seçilmiş ve Vali, } \\
\text { Kaymakam gibi atanmış kişilerin iletişimini içerir. }\end{array}$ \\
\hline Diğer/Bilinmeyen & $\begin{array}{l}\text { Bu kategori paylaşılan içeriğin hiçbir kategoriye yerleştirilememesi } \\
\text { sonucu ortaya çıkmıştır. Özellikle hesaplardan hiçbir açıklama } \\
\text { yapılmadan paylaşılan fotoğraflar bu kategoride kodlanmıştır. }\end{array}$ \\
\hline
\end{tabular}

Kaynak: Çelik ve Aktaş, 2017; Sobaci ve Karkin, 2013; Van Dijck, 2011

Cumhur İttifakı ve Millet İttifakı adaylarının tweet kategorilerini kullanım pratikleri incelendiğinde, Binali Yıldırım tarafından en sık kullanılan kategori seçim kampanyası iletişimi kategorisidir $(\% 26,8)$. Bu kategoriyi \%22,7 oran ile kişisel mesaj ve hemen ardından \%21,3 ile konum ve etkinlik kategorileri takip etmektedir. Binali Yıldırım tarafından en az kullanılan kategoriler ise, \%2 oran ile seçilmiş ve atanmışlarla iletişim ve \%3,9 ile kişilerarası diyalog kategorileridir. Diğer taraftan Ekrem İmamoğlu ise, en sık konum ve etkinlik kategorisini kullanmayı tercih etmiștir (\%38,6). Bu kategoriyi \%21,4 ile seçim kampanyası iletişimi ve \%20,8 ile kişisel mesaj kategorisi takip etmektedir. 
\%18 oran ile bilgi ve açıklama kategorisi Ekrem İmamoğlu tarafından en sık tercih edilen dördüncü kategoridir. Öte yandan Ekrem İmamoğlu diğer/bilinmeyen kategorisini hiç kullanmazken, kişilerarası diyalog kategorisini sadece bir kez ve seçilmiş ve atanmışlarla iletişim kategorisini ise üç kez kullanmıştır (Tablo 3).

Tablo 3: Adayların Tweet Kategorilerini Kullanım Pratikleri

\begin{tabular}{|l|l|c|c|c|c|c|c|}
\hline \multicolumn{2}{|c|}{} & \multicolumn{2}{c|}{ Binali YıIdırım } & \multicolumn{2}{c|}{ Ekrem İmamoğlu } & \multicolumn{2}{c|}{ Toplam } \\
\cline { 3 - 8 } & Konum ve Etkinlik & $\mathbf{N}$ & $\mathbf{\%}$ & $\mathbf{N}$ & $\mathbf{\%}$ & $\mathbf{N}$ & $\mathbf{\%}$ \\
\hline \multirow{4}{*}{$\begin{array}{l}\text { Tweet } \\
\text { Kategorileri }\end{array}$} & Seçim Kampanyası İletişimi & 115 & 21,3 & 137 & 38,6 & 252 & 28,1 \\
\cline { 2 - 8 } & Kişisel Mesaj & 145 & 26,8 & 76 & 21,4 & 221 & 24,7 \\
\cline { 2 - 8 } & Bilgi ve Açıklama & 123 & 22,7 & 74 & 20,8 & 197 & 22 \\
\cline { 2 - 8 } & Kişilerarası Diyalog & 69 & 12,8 & 64 & 18 & 133 & 14,8 \\
\cline { 2 - 8 } & Seçilmiş ve Atanmışlarla İletişim & 11 & 2 & 3 & 0,8 & 14 & 1,6 \\
\cline { 2 - 8 } & Diğer/Bilinmeyen & 57 & 10,5 & - & - & 57 & 6,4 \\
\cline { 2 - 8 } & TOPLAM & 541 & 100 & 355 & 100 & 896 & 100 \\
\hline
\end{tabular}

Adayların miting, toplantı, ziyaret, buluşma ve tv, radyo ve sosyal medya üzerinden gerçekleştirdikleri etkinlik ve programları içerisinde barındıran konum ve etkinlik kategorisi toplamda en fazla tercih edilen kategori olarak dikkat çekmektedir. Özellikle Millet İttifakı adayı Ekrem İmamoğlu tarafından bu kategori kampanya döneminde yoğun bir ş̧ekilde kullanılmıştır. Örneğin, @ekrem_imamoglu: “Doğu ve Güneydoğu Anadolu Bölgelerimizin kanaat önderleri ve yurttaşlarımız ile Küçükçekmece Akşemsettin Camii'nin konferans salonunda orucumuzu açtık; birliğimiz, beraberliğimiz ve kardeşliğimiz için dua ettik. Tutulan oruçları Allah kabul etsin" (17 Mayıs 2019). Diğer taraftan, konum ve etkinlik kategorisi Cumhur İttifakı adayı Binali Yıldırım tarafından en sık kullanılan üçüncü kategoridir (Şekil 2). Örneğin, @BY: “@@KucukkayaIsmail moderatörlügüunde gerçekleștirilen canlı yayında Sayın Ekrem İmamoğlu ile İstanbul'u enine boyuna konuştuk. Bu güzel yaz akşamında yayında ve yapımda emeği geçen tüm emekçi kardeşlerime ve bizi izleyen siz sevgili İstanbullulara sonsuz teșekkür ediyorum" (17 Haziran 2019).

Adayların gerçekleştirdiği icraatlar, vaatler, birbirlerine ve diğer kişi veya kurumlara yönelik eleştirileri gibi eylemlerin değerlendirildiği seçim kampanyası iletişimi kategorisi toplamda en çok kullanılan ikinci kategoridir. Adaylar içerisinde 31 Mart'taki ilk seçimde geride kalan Binali Yıldırım tarafından bu kategori daha sık bir şekilde kullanılmıştır. Özellikle İstanbullu vatandaşlara yönelik daha önce Bakan ve Başbakan iken gerçekleştirdiği icraatları ve İBB Başkanı seçilmesi halinde yapacağı hizmetleri tek tek Twitter üzerinden kamuoyu ile paylaşmıştır. Ayrıca bu kategori içerisinde bazen rakibi Ekrem İmamoğlu'na yönelik eleştiriler de yer almaktadır. Vaatler ile ilgili olarak örneğin, @BY: “Doğalgaza yüzde 10 indirim yapacağız. Bununla ilgili çalışmalar yaptırıyorum. Ayrıca, sosyal destek alan 80 bin ailenin doğalgaz faturasının 50 lirasını biz karşılayacağız \#YineBizYaparız" (28 Mayıs 2019). Diğer taraftan Ekrem İmamoğlu ise, her ne kadar rakibi kadar söz konusu bu kategoriyi kullanmasa da tüm tweet'leri içerisinde en sık kullandığı ikinci kategoridir. Kısa süreli İBB Başkanlığı döneminde gerçekleştirdiği icraatlar ve tekrar seçilirse yapacağı hizmetlerden bahseden Ekrem İmamoğlu, bunun yanı sıra özellikle rakibine ve YSK'ya yönelik eleștirileri de bu kategori içerisinde ciddi anlamda yer tutmuştur (Şekil 2). Örneğin, @ekrem_imamoglu: "İstanbul'da kurdukları israf düzeni devam etsin isteyenler hak, hukuk tanımadılar; milletin iradesini yok saydılar. 23 Haziran'da hak yerini bulacak \#HerŞeyÇokGüzelOlacak” (9 Haziran 2019). 
Yeniden gerçekleştirilen 23 Haziran İBB Başkanlığı seçimleri sürecinde kampanya döneminde Cumhur İttifakı ve Millet İttifakı adayları tarafından Twitter'da en sık kullanılan üçüncü kategori, kişisel mesaj kategorisidir. Adayların kendisi ile ilgili paylaşımlarının yanında, özel gün ve olaylar, gündemdeki konular, kutlamalar, anmalar, tebrikler, taziye dilekleri gibi siyasal bir mesaj içermeyip toplumsal olaylara yönelik paylaşımların söz konusu olduğu kişisel mesaj kategorisi 123 kez Cumhur İttifak adayı Binali Yıldırım tarafından kullanılarak en sık tercih edilen ikinci kategori olmuştur. Örneğin, @BY: "İstanbul Büyükşehir Belediye Başkanlığı için yarışan CHP adayı @ekrem_ imamoglu, SP adayı @gokcinarnecdet, VP adayı @milkeryucelve Bağımsız adayların Ramazan Bayramlarını tebrik ederim. Mevlam milletçe nice bayramlara bizleri ulaştırsın" (4 Haziran 2019). Diğer taraftan Ekrem İmamoğlu 74 tweet'inde tercih ettiği kişisel mesaj kategorisi üçüncü en sık kullandığı kategoridir (Şekil 2). Örneğin, @ekrem_imamoglu: “Spor Toto Süper Lig Lefter Küçükandonyadis Sezonu'nun şampiyonu Galatasaray Spor Kulübümüzü kutlarım. Tüm futbolcuları, teknik heyeti ve sarı-kırmızı renklere gönül vermiş taraftarları tebrik ederim" (19 Mayıs 2019).

Adaylar tarafından en sık kullanılan dördüncü kategori olan bilgi ve açıklama kategorisi, daha çok adayların resmi Twitter hesapları üzerinden yapmış oldukları bilgilendirici içerikler ve günlük gelişmelere yönelik yaptıkları açıklamalar bu kategori içerisinde değerlendirilmektedir. Her iki adayın da en sık kullandığı dördüncü kategori olan bilgi ve açıklamayı, tüm tweet'leri içerisinde oransal olarak Ekrem İmamoğlu daha çok kullanmıştır (\%18). İmamoğlu, 355 tweet'inin 64 tanesi bilgi ve açılklamaya yöneliktir. Örneğin, @ekrem_imamoglu: “Değerli hemşehrilerim, partimizin resmi bağış kampanyası dışındaki tüm talepler yasa dışıdır. Özellikle 02129752190 nolu telefondan yapılan dolandırıcılık girişimi için suç duyurusunda bulunulmuştur. Lütfen ismim kullanılarak yapılan sahte bağış taleplerini şikâyet ediniz" (17 Mayıs 2019). Öte yandan, Binali Yıldırım 541 tweet'inin 69 tanesinde bilgi ve açıklama kategorisini kullanmıştır (Şekil 2). Örneğin, @BY: "Neden çalındı diyoruz? Oylar çalınmamışsa 29 bin 400 olarak açıklanan fark 13 bin 700 seviyesine nasıl düştü? Yeniden sayım yapılıp düzeltmeler olunca her iki adayın da oy kazanıp veya kaybetmesi gerekirken fark bizim lehimize yarı yarıya azalıyor ve 29 binden 13 binlere düşüyor" (23 Mayıs 2019).

Adayların resmi Twitter hesapları üzerinden paylaştıkları içeriklerin söz konusu hiçbir kategoriye yerleştirilememesi sonucu ortaya çlkan diğer/bilinmeyen kategorisi, özellikle hesaplardan hiçbir açıklama yapılmadan paylaşılan fotoğrafları içerisinde barındırmaktadır. Millet İttifakı adayı Ekrem İmamoğlu tarafından hiç kullanılmayan bu kategoriyi, Cumhur İttifakı adayı Binali Yıldırım tüm tweet'leri içerisinde \%10,5 oranında kullanmıștır. Binali Yıldırım'ın 541 tweet'inin 57 tanesi diğer/bilinmeyen kategorisine

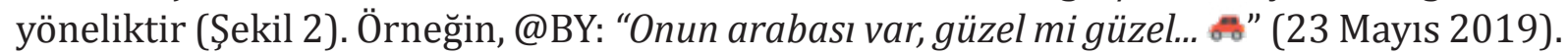

Web 2.0 ile birlikte sosyal medyanın en önemli katkılarından birisi olan iki yönlü iletişim süreci siyasal iletişim sürecini de etkilemiştir. Adayların diğer kullanıcılara mention şeklinde cevap vermesi ve cevap niteliğindeki alıntılama türü paylaşımlar kişilerarası diyalog kategorisinde yer almaktadır. Bu kategori, Twitter kullanıcıları arasındaki iki yönlü iletişimi göstermektedir. Adaylar söz konusu bu kategoriyi kullanmayı pek tercih etmemişlerdir. Binali Yıldırım tüm tweet'leri içerisinde \%3,9 oranında kişilerarası diyalog kategorisini kullanmayı tercih etmiştir. Örneğin, @BY: “@RumeysaKadak bu keyifli video için teşekkür ederim. Devamını bekliyorum Bunlar başlangıç, daha yapacak çok işimiz var gençler!” (14 Haziran 2019). Diğer taraftan Ekrem İmamoğlu kişilerarası diyalog kategorisini sadece bir kez kullanmıștır (Șekil 2). Örneğin, @ekrem_imamoglu, @_allper 
adlı kullanıcının, "Ekrem Imamoğlu, çocuklara tabletiyle hava attı” tweet'ini alıntılayarak " $\because-:$ " emojisi ile cevap vermiştir.

Araştırmada adaylar arasında toplamda en az kullanılan kategori, Cumhurbaşkanı, Parti Genel Başkanı, Milletvekili, Bakan, diğer Belediye Başkanları gibi seçilmiş ve Vali, Kaymakam gibi atanmış kişilerin iletişimini içeren seçilmiş ve atanmışlarla iletişim kategorisidir. Tüm tweet'leri içerisinde Binali Yıldırım \%2 ve Ekrem İmamoğlu da \%0,8 oranında bu kategoriyi kullanmıştır. Binali Yıldırım 11 tweet'inde bu kategoriyi kullanarak iki aday içerisinde en çok kullanan aday olarak öne çıkmaktadır. Örneğin, @BY: "Hak yerini buldu, @eyupaytekin Başkan oldu. \#AdaletYeriniBuldu Hayırlı olsun Yusufeli!" (2 Haziran 2019). Öte yandan, Ekrem İmamoğlu 355 tweet'inde sadece üç kez seçilmiş ve atanmışlarla iletişim kategorisini kullanmıștır (Şekil 2). Örneğin, @ ekrem_imamoglu: "Başta büyükşehir belediye başkanları olmak üzere toplantımıza ve Istanbul'daki çalışmalara katılan tüm belediye başkanlarımıza teşekkürler. @Y_Buyukersen @mansuryavas06@ZeydanKaralar01@SecerVahap @OZLEM_CERCIOGLU @tuncsoyer@ kadira59@DocDrLutfuSavas @BocekMuhittin @osmangurun” (23 Mayıs 2019).

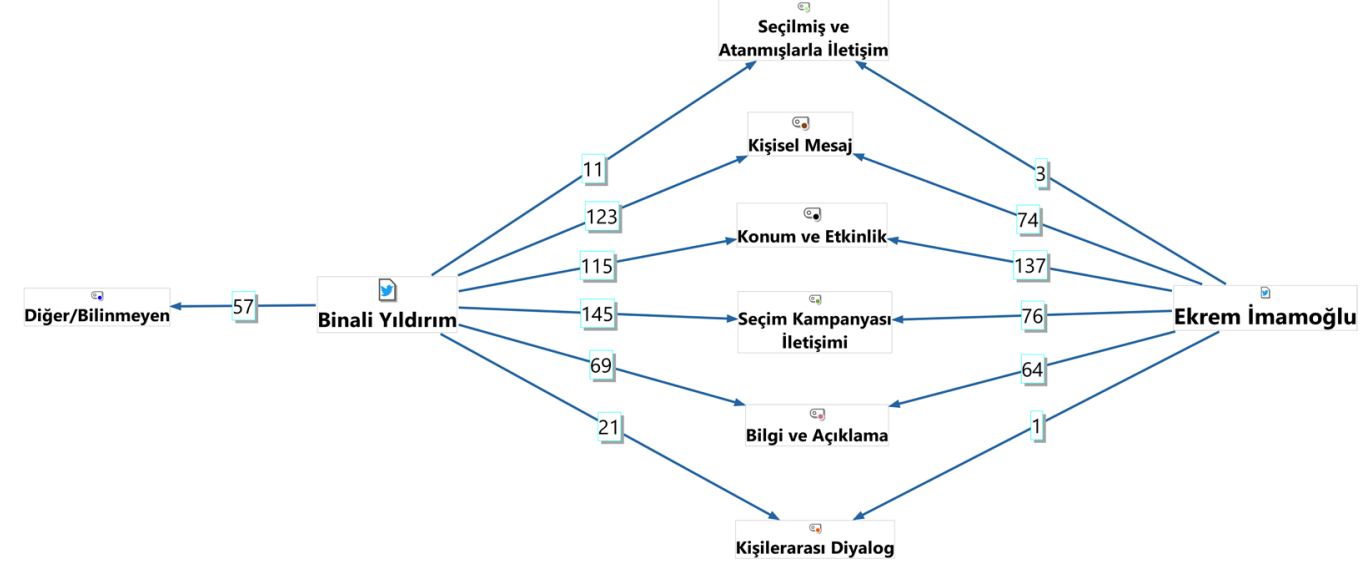

Şekil 2: Adayların Tweet Kategorilerini Kullanım ile İlgili İki-Vaka Modeli

\section{Hashtag Kullanımı}

Araştırmada Ekrem İmamoğlu 355 tweet'inde toplam 177 hashtag kullanımı ile en çok hashtag kullanan adaydır. Ekrem İmamoğlu, tüm tweet'leri içerisinde \%49,8 oranında hashtag kullanarak erişimini artırmaya, gündem oluşturmaya veya gündeme uygun içerikler paylaşmaya özen göstermiştir. Diğer taraftan Binali Yıldırım ise, 541 tweet'inde toplam 167 hashtag kullanmıştır. Binali Yıldırım'ın tüm tweet'lerinde hashtag kullanım oranı \%30,8'dir. Bunun yanı sıra, Binali Yıldırım toplamda 59 farklı hashtag kullanırken, Ekrem İmamoğlu 22 farklı hashtag kullanmıștır. Genel olarak değerlendirildiğinde ise, araştırmada tüm tweetler içerisinde (896) hashtag kullanım oranı \%38,3 oranındadır (Tablo 4).

Tablo 4: Adayların Hashtag Kullanım Pratikleri

\begin{tabular}{|l|c|c|c|c|}
\hline & \multirow{2}{*}{$\begin{array}{c}\text { Tweet } \\
\text { N }\end{array}$} & Farklı Hashtag & \multicolumn{2}{|c|}{ Toplam Hashtag } \\
\cline { 3 - 5 } & & & $\mathbf{N}$ & $\mathbf{\%}$ \\
\hline Binali Yıldırım & 541 & 59 & 167 & 30,8 \\
\hline Ekrem İmamoğlu & 355 & 22 & 177 & 49,8 \\
\hline TOPLAM & 896 & 81 & 344 & 38,3 \\
\hline
\end{tabular}

Cumhur İttifakı adayı Binali Yıldırım'ın en sık kullandığı hashtag \#YineBizYaparız olmuştur. Söz konusu hashtagi 61 kez tweet içeriklerinde kullanan Binali Yıldırım, geçmiş 
icraatlarından yola çıkarak vaatlerini bu hashtag üzerinden ortaya koymuştur. Bunun yanı sıra, 26 kez kullanılan \#DahaGüzelOlacak hashtag'i ile rakibine göndermede bulunan Binali Yıldırım, özellikle kampanyanın ilk evrelerinde bu hashtag'i daha sık kullanırken, ilerleyen süreçte seçim kampanyasını \#YineBizYaparız hashtag'i üzerinden yürütmeyi tercih etmiștir. Ayrıca \#İşEhlininKararMiletin ile \#İşEhlinin hashtag'lerini de Binali Ylldırım zaman zaman kullanmakta ve daha önce gerçekleştirdiği hizmet ve icraatlara göndermede bulunarak bu işi en iyi kendisinin yapabileceğini hashtag'ler yoluyla ileri sürmektedir (Şekil 3).

Millet İttifakı adayı Ekrem İmamoğlu ise, tüm seçim kampanyasını “\#HerşeyÇokGüzelOlacak" slogan ve hashtag'i üzerine kurmuştur. 31 Mart seçimlerinde Başkan seçilmesine rağmen YSK tarafından seçimin iptal edilmesine Ekrem İmamoğlu büyük tepki göstermiş fakat seçmenlere umut ve inanç aşılamak için bu slogan ve hashtag ile seçim çalışmalarını yürütmüştür. Bu slogan, seçim çalışmaları sırasında bir çocuk tarafından dile getirilmiş ve daha sonra toplumun geneline yayllarak büyük bir etki uyandırmıştır (Yeniçağ, 2019). Söz konusu bu slogan (hashtag) Ekrem İmamoğlu'nun Twitter içeriklerinde $148 \mathrm{kez}$ kullanılmış ve bu hashtag ile ayrıca seçilmesi halinde gerçekleştireceği vaatler ve projeler kamuoyu ile paylaşılmıştır. Öte yandan hem Binali Ylldırım hem de Ekrem İmamoğlu tarafından ortak kullanılan hashtag'ler ise, daha çok gündem ile alakalı hashtag'lerdir. \#19MAYIS1919, \#AnnelerGünü, \#BabalarGünü ve \#F4GLORY adaylar tarafından en sık kullanılan ortak hashtagler'dir (Şekil 3).

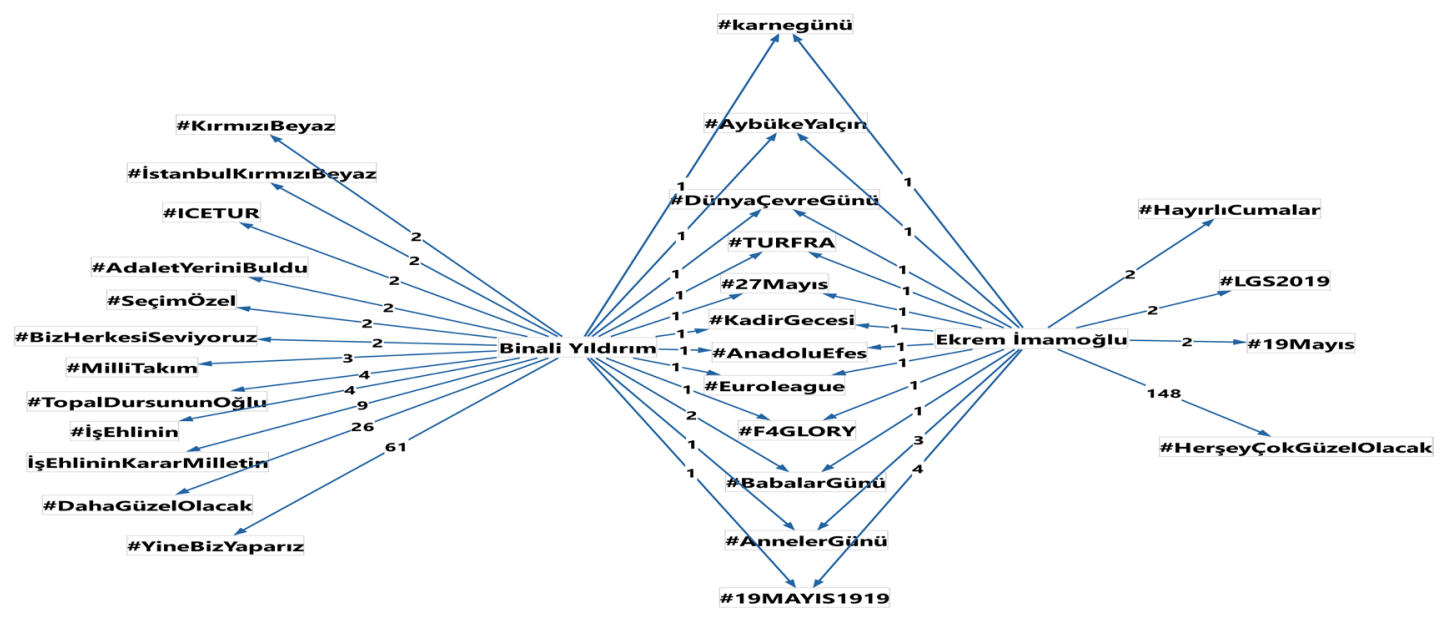

Şekil 3: Adayların Twitter İçeriklerinde Hashtag Kullanım ile İlgili İki-Vaka Modeli

Hashtag'ler, tweet içeriklerinin sınıflandırılması ile ilgili ipuçları da verebilmektedir. $\mathrm{Bu}$ varsayımdan yola çıkarak tweet kategorileri ile kullanılan hashtag'ler arasındaki ilişkiye bakılmıştır. Şekil 4'e bakıldığında, en yoğun ilişkinin Binali Yıldırım'a ait olan \#YineBizYaparız hashtag'i ile konum ve etkinlik kategorisi ve yine Yıldırım'a ait olan \#İşEhlininKararMilletin hashtag'i ile seçim kampanyası iletişimi arasında olduğu görülmektedir. Ayrıca \#YineBizYaparız hashtag'i ile seçim kampanyası iletişimi kategorisi arasında da orta düzeyde bir ilişki vardır. Tüm bunların yanı sıra, Binali Yıldırım'a ait olan \#SeçimÖzel ve Ekrem İmamoğlu'na ait olan \#HerşeyÇokGüzelOlacak hashtag'leri ile konum ve etkinlik kategorisi arasında düşük düzeyde de olsa bir ilişki söz konusudur. 


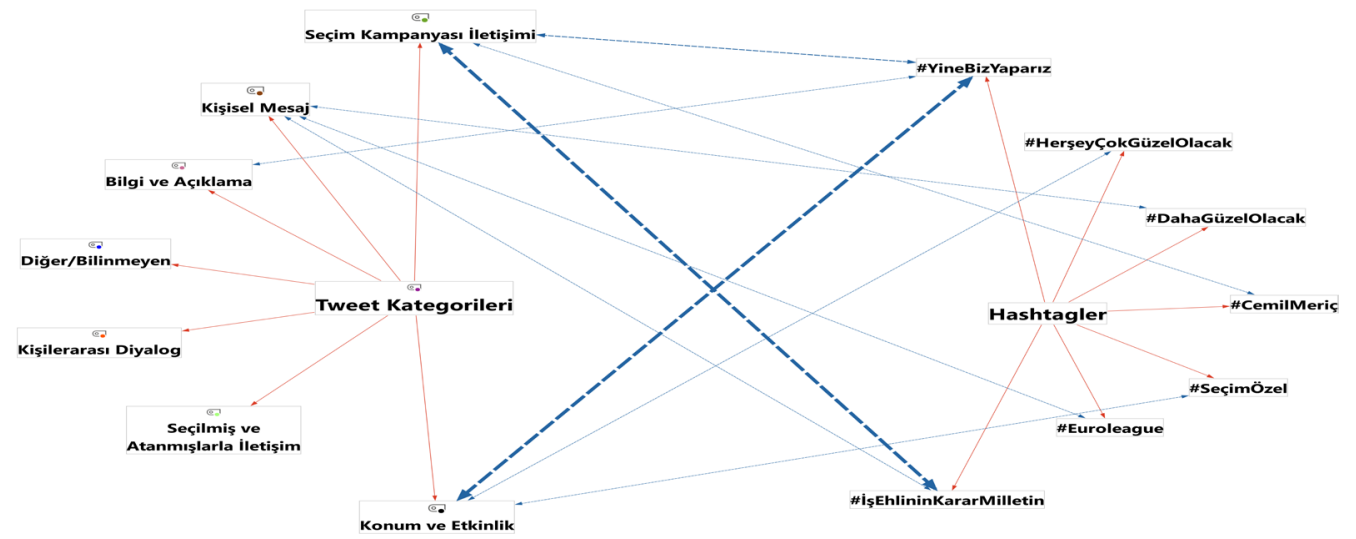

Şekil 4: Tweet Kategorileri ile Hashtag'ler Arasındaki Illișki Matrisi

\section{Kelime Analizi}

Araştırmada adayların Twitter verilerine Maxqda programı vasıtasıyla içerik taraması uygulandığında kelime bulutları ortaya çıkmaktadır. Kelime bulutlarına, anlamsız kelime ve sözcükler ile hashtag ve mention'lar dâhil edilmemiştir. En sık kullanılan kelimeler en büyük boyutta gösterilirken kullanım sayısı azaldıkça kelimenin görseldeki boyutu da küçülmektedir.

Cumhur İttifakı adayı Binali Yıldırım'ın Twitter içeriklerinde kullandığı kelimeler incelendiğinde, 'İstanbul' en sık kullanılan kelime olarak öne çıkmaktadır. Binali Yıldırım söylemlerinde sürekli olarak, 'İstanbul', 'İstanbulumuz', 'İstanbullular' gibi kelimelerden bahsederek Twitter kampanyasını yürütmüştür. Öte yandan Yıldırım seçmen kitlesine seslenirken, 'hemşehrilerim', 'kardeşlerim' gibi kelimelerle seslenerek onlara yakınlık hissi veren ifadelerle yaklaşmaya özen göstermiștir. Bunun yanı sıra, 'birlikte', 'beraber', 'biz', 'insan', 'ortak', 'sevgi', 'millet' gibi kelimeleri sıklıkla kullanan Binali Yıldırım, birliktelik üzerinde önemle durmakta, aday ile vatandaş arasındaki bağlılığa ve pozitif kampanya diline vurgu yapmaktadır. Diğer taraftan, Binali Yıldırım 'ben' zamirini zaman zaman kullanmıştır. Bu durum diğer aday Ekrem İmamoğlu'nun paylaşımlarında söz konusu değildir. 'Ben' zamiri aynı zamanda kendine güvenin bir ifadesi olarak düşünülebileceği gibi egolu bir kişisel özelliğin yansıması olarak da zaman zaman değerlendirilmektedir (Doğan ve Ertan, 2016, s. 152). 'Hizmet', 'proje', 'müjde', 'ulaşım', 'ücret', 'lira', 'öğrenci', 'gelecek', 'çalışacağız', 'yapacağız', 'şehir', 'genç', 'aile' gibi kelimeleri sıklıkla kullanarak icraat, vaat ve hizmetler gibi seçim kampanyası iletişimi kategorisine yönelik içerikler paylaşmaktadır. Son olarak, 'tebrik', 'hayırlı', 'bayram', 'Allah', 'inşallah', 'teșekkür', 'rahmet', 'şehit' gibi daha çok kişisel mesaj kategorisine yönelik kelimeleri Binali Yıldırım kullanmayı tercih etmiștir (Şekil 5).

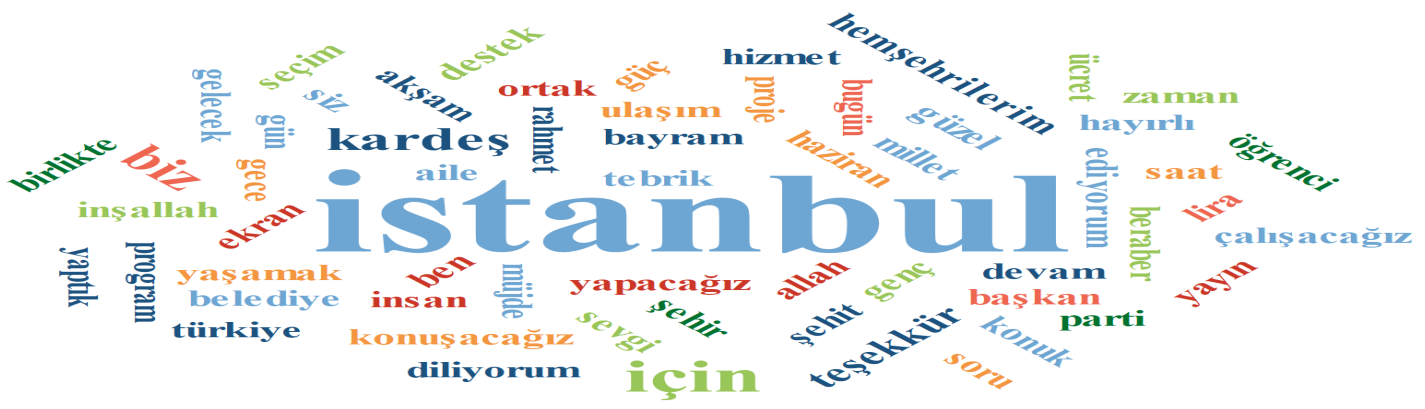

Şekil 5: Binali Yıldırım'ın Kelime Bulutu 
Millet İttifakı adayı Ekrem İmamoğlu'nun kelime bulutuna bakıldığında ise, yine 'İstanbul' en sık kullanılan kelimedir. Ekrem İmamoğlu 'adalet', 'hak', 'demokrasi', 'mücadele', 'cumhuriyet', 'sandık' gibi kelimeleri sıklıkla kullanarak 31 Mart seçim sonuçlarına göndermede bulunmakta ve kendisine haksızlık yapıldığını vurgulamaya çalışmaktadır. Ayrıca İmamoğlu, 'iş', 'çocuk', 'aile', 'genç', 'şehir' gibi kelimelerle vatandaşlara yönelik vaatlerini sıralamaktadır. Aynı zamanda 'sevgi', 'kardeș', 'gönül', 'güzel', 'insan', 'mutlu' gibi sık kullanılan kelimelerden yola çıkarak Ekrem İmamoğlu'nun pozitif bir seçim kampanyası yürüttüğ̈nü söylemek mümkündür. Bunun yanı sıra İmamoğlu'nun, 'beraber', 'birlikte', 'kardeș', 'millet', 'vatandaşımız', 'herkes', 'hemşehrilerim' gibi birlik, beraberlik ve sıcaklık içeren kelimeleri kullanması vatandaşa yönelik kucaklayıcı bir dile sahip olduğunu göstermektedir (Şekil 6).

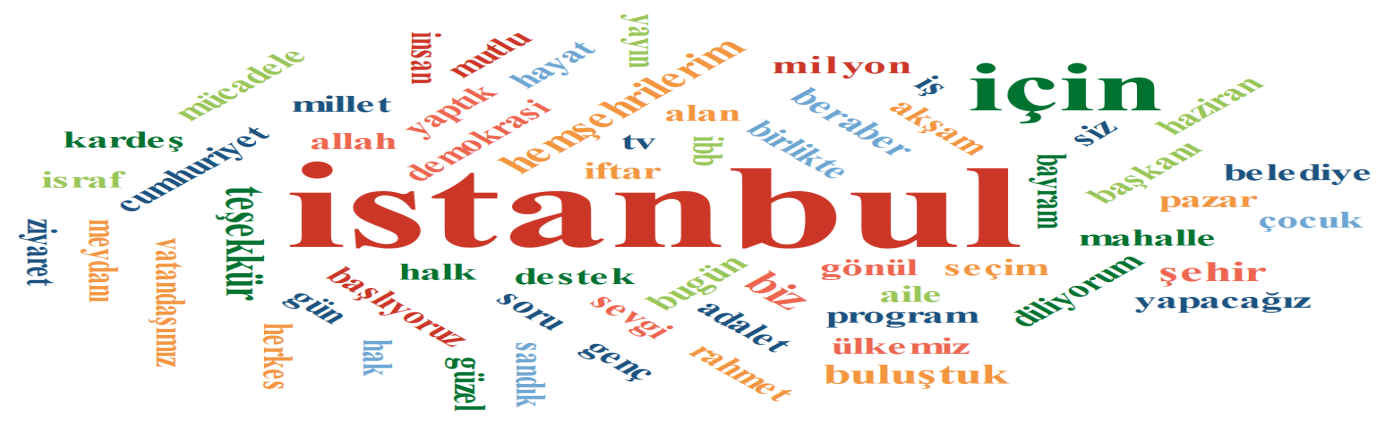

Şekil 6: Ekrem İmamoğlu'nun Kelime Bulutu

'Saat', 'gün', 'akşam', 'gece', 'yayın', 'soru', 'program' gibi kelimelerin her iki aday tarafından da çok fazla kullanılması, paylaşımlarda miting, toplantı, tv, radyo ve sosyal medya programları ve benzeri etkinliklerin tarih, saat, yer, program gibi bilgilerin paylaşılmasından dolayı ortaya çıktığı söylenebilir. Ayrıca 'için' edatının kullanımında ise daha çok seçim kampanyasına yönelik içerikleri nedene bağlama amacı bulunmaktadır. Örselli vd. (2018, s. 708)'nin vurguladığı gibi, kullanılan ifadeleri bir nedene bağlayarak daha geçerli hale getirmek adına 'için' edatı sıklıkla her idi aday tarafından da kullanılmıştır. Son olarak, iki aday tarafından da sık kullanılan 'Haziran', 'seçim' ve 'destek' gibi kelimelerin kullanılması adayların 23 Haziran 2019 tarihinde gerçekleşecek olan seçime yönelik vatandaşlardan destek beklediğini göstermektedir.

\section{Sonuç ve Tartışma}

23 Haziran 2019 İBB Başkanlığı seçiminde, Cumhur İttifakı AK Parti adayı Binali Yıldırım ve Millet İttifakı CHP adayı Ekrem İmamoğlu'nun tarafından Twitter'ın siyasal iletişim açısından seçim kampanyası döneminde nasıl kullanıldığını incelemeyi amaçlayan bu araştırmada, Binali Yıldırım'ın Twitter'ı Ekrem İmamoğlu'na göre daha çok kullandığı ortaya çıkmıştır. Ayrıca toplamda iki aday günlük olarak ortalama 10 tweet paylaşmaktadırlar. Bu bulgu, Dumlu (2018) ile Tongut ve Akman (2014)’ın bulguları ile uyumsuzluk göstermektedir. Dumlu (2018) yaptığı araştırmada siyasi adayların günlük ortalama tweet paylaşım oranını daha düşük bulmuştur. Tongut ve Akman (2014) ise, 2014 İBB Başkanlığı seçimlerinde CHP adayı Mustafa Sarıgül'ün seçim öncesi kampanya döneminde günlük ortalama 30 tweet attığını tespit etmiştir. İmamoğlu bir önceki seçimde aynı partiden aday olan Sarıgül'e göre günlük ortalama neredeyse dört kat daha az sayıda takipçileri ile tweet paylaşmasına rağmen Sarıgül'ün aksine seçimin kazananı olmuştur. Öte yandan, çalışmada adayların seçim tarihi yaklaştıkça Twitter kullanım oranlarının arttığı gözlemlenmektedir. Bu durum İkiz vd. (2014)'nin bulguları ile benzerlik göstermektedir. 
Araştırmada adayların tweet kategorilerini kullanım pratikleri ile ilgili olarak toplam yedi kategori meydana getirilmiștir. Adaylar tarafından en sık kullanılan kategori, konum ve etkinlik kategorisidir. Adayların katıldığı veya katılacağı etkinlikler hakkında içerik paylaşmayı benimsedikleri görülmektedir. Adaylar tarafından en sık kullanılan ikinci kategori ise, seçim kampanyası iletişimi kategorisidir. Bu kategori, takipçilerin veya seçmenlerin politikacılar tarafından paylaşılan içerikleri nasıl yorumlayabilecekleri konusunda bilgilendirme yapılarak, seçim iletişimi faaliyetlerinin karmaşıklığı yönetilir ve basitleştirilir (Jensen ve Anstead, 2014). Adaylar tarafından sık kullanılan bir diğer kategori de kișisel mesaj kategorisidir. Kișisel mesajlar (kişiselleștirme), politikacılar tarafından Twitter'da yaygın olarak kullanılmakta ve adayın kişiliğine odaklanarak daha kişisel bir imajın ortaya çıkmasına neden olmaktadır (Triantafillidou vd., 2018, s. 68). Son olarak adaylar tarafından sıklıkla kullanılan son kategori de bilgi ve açıklama kategorisidir. Hedef kitleleri olan seçmenleri Twitter üzerinden bilgilendirmek ve gelişmelerden haberdar etmek için adaylar tarafından bu kategori yoğun bir şekilde kullanılmaktadır.

Araştırmada adaylar tarafından en az kullanılan kategorilerden bir tanesi, etkileşimi içinde barındıran kişilerarası diyalog kategorisidir. Araştırmaya göre sosyal medyanın en önemli kazanımlarından biri olan etkileşime açık olma özelliği parti ve siyasetçiler tarafından nadir olarak kullanılmaktadır. Söz konusu bu politika uygulayıcıları, takipçileri ile tek taraflı içerik paylaşmakta ve daha çok takipçiler tarafından sosyal medyanın etkileşim özelliği kullanılmaktadır. Bu durum iki yönlü iletişime olanak tanıyan web 2.0’ın doğasıyla çelişmektedir. Bu çelişkinin en temel sebebi, politikacıların Twitter takipçilerini iki yönlü iletişimin bir tarafı olmaktan ziyade öncelikle kendilerinin bir destekleyicileri, başka bir ifadeyle 'zaten ikna olmuş seçmen' olarak görmelerinden kaynaklanmakta olduğu ileri sürülmektedir (Mirer ve Bode, 2013; Ramos-Serrano vd., 2018). Özet olarak, Twitter gibi sosyal medya platformları her ne kadar iki yönlü bir iletişim sürecine önemli bir katkı sunsa da politikacılar gibi seçkinler tarafından bu platformların kullanımı çoğunlukla asimetrik kalmıştır (Ramos-Serrano vd., 2018). Çalışmada bir diğer az kullanılan kategori, adaylar tarafından paylaşılan içeriğin hiçbir kategoriye yerleştirilememesi sonucu ortaya çıkmış olan diğer/bilinmeyen kategorisidir. Binali Yıldırım'ın özellikle hiçbir ileti yazmadan paylaştığı fotoğraflar bu kategori de değerlendirilmiştir. Son olarak, araştırmada adaylar tarafından en az kullanılan tweet kategorisi ise, seçilmiş ve atanmışlarla iletişim kategorisidir.

Literatürde yer alan Twitter'ın siyasal iletişim çabalarında kullanımına ilişkin araștırma bulguları, mevcut çalışmadaki bulgular ile benzerlikler ve farklılıklar göstermektedir. Alandaki önemli çalışmalardan bazıları adayların veya politikacıların Twitter kullanımının temel amaçlarının; konum ve etkinlik bilgilerinin paylaşımı (İkiz vd., 2014; Örselli vd., 2018), seçim kampanyası iletişimine yönelik paylaşımlar (Ahmed vd., 2016; Bayraktutan vd., 2014; Çelik ve Aktaş, 2017; İkiz vd., 2014; Marques ve Mont'Alverne, 2016; Ramos-Serrano vd., 2018; Sukmayadi vd., 2019; Tongut ve Akman, 2014), kişisel mesaj paylaşımları (Doğan ve Ertan, 2016; Honeycutt ve Herring, 2009; Sobaci ve Karkin, 2013; Triantafillidou vd., 2018) ile bilgi ve açılama türü paylaşımlar (Çelik ve Aktaş, 2017; Doğan ve Ertan, 2016; Honeycutt ve Herring, 2009; Lilleker vd., 2011; Örselli vd., 2018; Sobaci ve Karkin, 2013) olduğunu ileri sürmektedirler. Öte yandan, etkileşimi açıklayan kişilerarası diyalog kategorisinin araştırmaya göre çok az kullanılmasıyla ilgili literatürdeki bazı çalışmaların bulguları desteklenirken (Adams ve McCorkindale, 2013; Bayraktutan vd., 2014; Çelik ve Aktaș, 2017; Marques ve Mont'Alverne, 2016; Örselli vd., 2018; Ramos-Serrano vd., 2018; Triantafillidou vd., 2018), bazı çalışmalar 
desteklememektedir (İkiz vd., 2014; Lilleker vd., 2011; Sobaci ve Karkin, 2013). Ayrıca seçilmiş ve atanmışlarla iletişim (Sobaci ve Karkin, 2013) ve paylaşımların belirli bir amaç doğrultusunda paylaşılmamasını içeren diğer/bilinmeyen kategorilerine yönelik de benzerlikler söz konusudur (Honeycutt ve Herring, 2009; Marques ve Mont'Alverne, 2016; Sobaci ve Karkin, 2013).

Söz konusu bu çalışmada her ne kadar hashtag kullanımı adaylar arasında yaygın olsa da Sukmayadi vd. (2019)'nin bulgularının aksine, retweet ve mention konularında önemli eksiklik vardır. Genel olarak değerlendirildiğinde, araştırmada her iki adayın tüm tweet'leri içerisinde hashtag kullanım oranı, Triantafillidou vd. (2018)'nin öne sürdüğü hashtag kullanım oranından çok daha fazla iken, Doğan ve Ertan (2016)'ın bulduğu orana daha yakın olduğu gözükmektedir. Bunun yanı sıra, Ekrem İmamoğlu tüm seçim kampanyasını \#HerşeyÇokGüzelOlacak slogan ve hashtag'i üzerinden yürütürken, Binali Yıldırım \#YineBizYaparız slogan ve hashtag'i üzerinden seçim kampanyasını sürdürmüștür. Araștırmada, Binali Yıldırım'ın \#YineBizYaparız hashtag'i ile konum ve etkinlik kategorisi arasında ve yine Yıldırım'a ait olan \#İşEhlininKararMilletin hashtag'i ile seçim kampanyası iletişimi kategorisi arasında ileri düzeyde bir ilişki tespit edilmiștir. Benzer bir şekilde Doğan ve Ertan (2016) araştırmalarında Hillary Clinton'un tweet'lerinde kullanılan hashtag'ler ile slogan ve vaatler arasında ilişki bulmuşlardır. Çalışmada ayrıca adayların toplanan tüm tweet'lerinde geçen kelimeler kullanım sıklıklarına göre değerlendirilmiştir. Söz konusu iki adayda beklenildiği gibi en sık 'İstanbul' kelimesini kullanmıştır. Adayların kullandığı kelimeler daha çok icraat, vaat ve eleştirilerini sıraladıkları seçim kampanyası iletişim kategorisine ve dilek, temenni, kutlama, anma gibi içerikleri kapsayan kişisel mesaj kategorisine yöneliktir. Bunun yanı sıra, 'biz', 'ben', 'aile', 'işçi', 'insan', 'medya', 'kadın', 'oy' gibi 2016 ABD Başkanlık seçimlerinde Donald Trump ve Hillary Clinton'un en sık kullandığı kelimeler (Doğan ve Ertan, 2016), 23 Haziran 2019 İBB Başkanlığı seçim sürecinde adaylar tarafından sıklıkla kullanılmıştır.

Araştırmadaki bulgular genel olarak değerlendirildiğinde, günümüzde sosyal medya, siyasi parti ve politikacılar için yeni siyasal iletişim kurma alanlarından birisi haline gelmiştir. Bireyler tarafından sosyal medyanın yoğun bir şekilde kullanılması hem seçim dönemleri hem de seçim olmayan dönemlerde sosyal medyanın önemini daha da artırmaktadır. Sosyal medya platformları, politikacılar adına kolay siyasal iletişim ve propaganda yapma platformu olması açısından önem taşımaktadır (Kılıçaslan, 2016, s. 147). Bazı politikacılar sosyal medyayı sadece diğerlerinden geride kalmamak için kullanırken, bazıları da temel iletişim stratejilerinin bir parçası olarak değerlendirmektedirler (Effing vd., 2013, 59). Twitter başta olmak üzere sosyal medyanın, tüm siyasi partiler için 'yeni bir güç’ oluşturduğu açıkça söylenebilir (Bayraktutan vd., 2014, s. 196).

Literatürde her ne kadar siyasal iletişim bağlamında 'yeni bir güç' olarak tabir edilen sosyal medya kullanımının önemi ortaya konulsa da Güz vd. (2019, s. 1477)'nin belirttiği gibi, diğer birçok değişkenin politik başarı üzerindeki belirleyiciliği unutulmaması gerekmektedir. Bu değişkenler ile beraber değerlendirildiğinde, 23 Haziran 2019 İBB Başkanlığı seçimini, daha az aktif Twitter kullanan ve etkileşim boyutunda neredeyse hiç kullanmayan Ekrem İmamoğlu kazanmıştır. Bu durum, Marques ve Mont’Alverne (2016)'nin bulguları ile örtüşmektedir. Ayrıca Twitter verileri gibi sosyal medya verileri seçim başarısı açısından bir ipucu olduğu kadar aynı zamanda pek güvenilir olmayan zayıf bir göstergedir (Vepsäläinen vd., 2017). Başka bir deyişle, Twitter’ın tek başına kendine özgü önemli bir politik etkisi ve değeri olmadığı yönünde dikkat çekici bir yaklaşım söz 
konusudur (Ramos-Serrano vd., 2018). Twitter, özellikle küçük aktörlerin bir cazibe kazanmasına izin verebilir, ancak bu cazibenin doğrudan geleneksel çevrimdışı politik başarıya dönüşmesi şu an için pek gerçekçi gözükmemektedir (Larsson, 2018). Ayrıca Karlsen ve Enjolras (2016), Twitter gibi sosyal medya platformlarında belirli bir nüfuza sahip olan adayların, geleneksel medya araçları ve sosyal medya arasında bir sinerji yaratabilenler olduğunu ileri sürmektedirler.

Söz konusu bu araştırmada bazı sınırlıklar vardır. Bu çalışmada adayların sadece Twitter hesapları üzerinden paylaştıkları içerikler incelenmiştir. Diğer sosyal medya hesaplarından paylaşılan içerikler dikkate alınmamıştır. Ayrıca Twitter'da kullanıcıların diğer kullanıcılara cevap vermesi ve paylaşılan içerikte diğer kullanıcıların etiketlenmesi şeklinde Twitter'da iki şekilde mention kullanımı vardır. Bu çalışmada, adayların diğer kullanıcılara cevap vermesi şeklindeki mention'lar değerlendirmeye alınırken, düz bir tweet yoluyla etiketleme yapılmış olan mention'lar dikkate alınmamıştır. Bunun yanı sıra adayların, kendileri tarafından paylaşılan düz tweet'ler ve alıntılamalar tweet kategorilerinde değerlendirilmiş fakat diğer hesaplardan yaptıkları retweet'ler analiz kapsamı dışında tutulmuştur. Bir başka sınırlılık ise, bu çalışmanın seçim kampanyasının en yoğun olduğu dönemi ele alıyor olmasıdır. Seçim sonrası dönem çalışmada incelenmemiştir.

Genel seçimlerde Twitter kullanımı ilgili literatürde oldukça fazla sayıda çalışma mevcutken, yerel seçimlerde sosyal medyanın siyasal iletişim bağlamında kullanımı ile ilgili çalışmalara ihtiyaç vardır. Bu konuda bir başka ihtiyaç da seçim kampanyası dönemlerinde analiz edilen hesapların, kampanyanın bittiği seçim sonrası dönemde (özellikle kaybedenler için duraklama dönemi) çok fazla incelenmediği görülmektedir. Literatürde hem seçim öncesi hem de seçim sonrası dönemlerde kiyaslamalı olarak Twitter kullanımı konusunda çok az çalışma vardır (Çelik ve Aktaş, 2017; Triantafillidou vd., 2018). Bu noktadan hareketle, gelecekte yapılacak olan çalışmalar, seçim öncesi ve seçim sonrası dönem şeklinde karşılaştırılarak yapılmalıdır. Ayrıca 31 Mart seçimleri ve yeniden gerçekleştirilen seçim olan 23 Haziran seçimleri sürecinde İBB Başkan adaylarının Twitter veya diğer sosyal medya platformlarını kullanım pratikleri, bazı çalışmalarda olduğu gibi (Bruns ve Moon, 2018; Larsson, 2018; Tarai, 2019) karşılaştırmalı olarak araștırmacılar tarafından incelenmelidir. Son olarak, İBB Başkan adaylarının sosyal medya kullanımlarının seçmen davranışı üzerinde etkili olup olmadığını belirlemek adına nitel bir odak grup veya mülakat çalışması ya da nicel bir anket çalışması önerilmektedir.

\section{Kaynakça}

Adams, A. ve McCorkindale, T. (2013). Dialogue and transparency: A content analysis of how the 2012 presidential candidates used Twitter. Public Relations Review, 39(4), 357-359. Doi: 10.1016/j.pubrev.2013.07.016

Anstead, N. ve O'Loughlın, B. (2012). Semantic Polling The Ethics of Online Public Opinion, Mediapolicybrief, LSE Media Policy Project. Access address: http://eprints.lse. ac.uk/46944/

Ahmed, S., Jaidka, K. ve Cho, J. (2016). The 2014 Indian elections on Twitter: A comparison of campaign strategies of political parties. Telematics and Informatics, 33, 10711087. Doi: $10.1016 /$ j.tele.2016.03.002

Aziz, A. (2015). Siyasal İletişim (6. Bs.). Ankara: Nobel Yayınları. 
Bayraktutan, G., Binark, M., Çomu, T., Doğu, B., İslamoğlu, G. ve Aydemir, T. A. (2012). Sosyal medyada 2011 genel seçimleri: Nicel-nitel ara yüzey incelemesi. Selçuk İletişim Fakültesi Dergisi, 7(3), 5-29. Erişim adresi: https://dergipark.org.tr/download/ article-file/234770

Bayraktutan, G., Binark, M., Çomu, T., Doğu, B., İslamoğlu, G. ve Aydemir, T. A. (2014). The use of Facebook by political parties and leaders in the 2011 Turkish General elections. B. Pătruț ve M. Pătruț (eds.). In Social Media in Politics (s. 165-199). Cham: Springer. Doi: 10.1007/978-3-319-04666-2_10

Bossetta, M. (2018). The digital architectures of social media: Comparing political campaigning on Facebook, Twitter, Instagram, and Snapchat in the 2016 U.S. Election. Journalism \& Mass Communication Quarterly, 95(2), 471-496. Doi: $10.1177 / 1077699018763307$

Bruns, A., ve Moon, B. (2018). Social media in Australian Federal Elections: Comparing the 2013 and 2016 campaigns. Journalism \& Mass Communication Quarterly, 95(2), 425-448. Doi: 10.1177/1077699018766505

Budak, E. (2018). Sosyal medyada propaganda süreçleri: 2017 referandum örneği. Anadolu Üniversitesi İletişim Bilimleri Fakültesi Uluslararası Hakemli Dergisi, 26(2), 39-55.

Christensen, C. (2013) WAVE-RIDING AND HASHTAG JUMPING Twitter, minority 'third parties' and the 2012 US elections, Information, Communication \& Society, 16(5), 646-666. Doi: 10.1080/1369118X.2013.783609

CNN Türk (6 Aralık 2018). Cumhurbaşkanı Erdoğan duyurdu: AK Parti'den flaş bayrak ve afiş kararı, Erişim adresi: https://www.cnnturk.com/turkiye/cumhurbaskanierdogan-14-ilin-belediye-baskan-adayini-acikladi.

Conover, D. M., Ratkiewicz, J., Francisco, R. M., Goncalves, B., Menczer, F., ve Flammini, A. (2011). Political polarization on Twitter. Fifth International AAAI Conference on Weblogs and Social Media (Icwsm), Menlo Park, California. Access address: https:// www.aaai.org/ocs/index.php/ICWSM/ICWSM11/paper/viewFile/2847/3275

Criado, J. I., Martínez-Fuentes G. ve Silván, A. (2012). Social media for political campaigning. the use of Twitter by Spanish Mayors in 2011 local elections. C. Reddick ve S. K. Aikins (eds.). In Web 2.0 Technologies and Democratic Governance (s. 219-232). New York: Springer. Doi: 10.1007/978-1-4614-1448-3_14

Çelik, F. ve Aktaș, H. (2017). Siyasal iletişimde Twitter kullanımı: "1 Kasım 2015 genel seçimleri öncesi ve sonrası dönemde siyasal partilerin Twitter kullanımları üzerine karşılaştırmalı bir analiz". I. Uluslararası Sosyal Bilimler ve Eğitim Araştırmaları Sempozyumu (Iscer) Bildiri Kitabı (s. 457-476) içinde. Ankara: Nobel Yayıncılık.

Demirhan, K. (2017). Türkiye'de 2017 anayasa referandumu sürecinde siyasal iletişim aracı olarak Twitter kullanımı. Erciyes İletişim Dergisi Akademia, 5(2), 262-280. Doi: $10.17680 /$ erciyesakademia.312287

Dijck, J. V. (2011). Tracing Twitter: The rise of a microblogging platform. International Journal of Media \& Cultural Politics, 7(3), 333-348. Doi: 10.1386/macp.7.3.333_1

Doğan, A. ve Ertan, T. (2016). Siyasal iletişim aracı olarak ABD Başkanlık Seçimlerinde Twitter'ın Kullanımı: Hillary Clinton ve Donald Trump örneği. Atatürk İletişim Dergisi, 11, 139-158. Erişim adresi: https://dergipark.org.tr/download/articlefile/398088 
Dumlu, H. (2018). Siyasal iletişim süreci olarak Cumhurbaşkanı adaylarının Twitter hesaplarının içerik çözümlemesi: 24 Haziran 2018 seçimleri. Osmaniye Korkut Ata Üniversitesi İktisadi ve İdari Bilimler Fakültesi Dergisi, 2(2), 200-211. Erişim adresi: https://dergipark.org.tr/download/article-file/610819

Effing, R., Hillegersberg, J. ve Huibers, T. (2013). Social media participation and local politics: A case study of the Enschede Council in the Netherlands. M. Z. Sobaci (ed.). In Electronic Participation (s. 57-68). Berlin: Springer. Doi: 10.1007/978-3-31917722-9_15

Emiroğlu, B. (2019). Siyasal iletişimde Twitter'ın kullanımı: Referandum örneği (15 Mart15 Nisan 2017). Akademik Sosyal Araştırmalar Dergisi (Sobider), 37, 516-528. Doi: 10.16990/SOBIDER.5004

Fidan, Z. (2015). Siyasal iletişim kampanyalarında yeni iletişim teknolojilerinin kullanımı: "2015 genel seçimleri dönemi web sayfaları ve sosyal medya kullanımları" (Yayınlanmamıș Doktora Tezi). Selçuk Üniversitesi Sosyal Bilimler Enstitüsü, Konya.

Genel, M. G. (2012). Siyasal iletişim kampanyalarında sosyal medyanın kullanımı (12 Haziran 2011 seçimleri “Twitter" örneği). The Turkish Online Journal of Design, Art and Communication, 2(4), 23-31. Erişim adresi: https://dergipark.org.tr/ download/article-file/138344

Güdekli, A. (2016). Yeni medyada siyasal söylem: 7 Haziran 2015 milletvekili genel seçimi sürecinde siyasi liderlerin Twitter kullanımı. Celal Bayar Üniversitesi Sosyal Bilimler Dergisi, 14(1), 131-154. Doi: 10.18026/cbusos.20779

Güz, N., Yegen, C. ve Aydın, B. O. (2019). Dijital propaganda ve politik başarı: 24 Haziran 2018 Cumhurbaşkanlığı seçiminin Twitter analizi. Erciyes İletişim Dergisi, 6(2), 1461-1482. Doi: 10.17680/erciyesiletisim.522546

Honeycutt, C. ve Herring, C. S. (2009). Beyond microblogging: Conversation and collaboration via Twitter. In Proceedings of the 42nd. Hawaii International Conference on System Sciences (HICSS '09) (s. 1-10). Hawaii, USA: IEEE Press. Doi: 10.1109/ HICSS.2009.89

Ifukor, P. (2010). "Elections" or "selections"? Blogging and Twittering the Nigerian 2007 general elections. Bulletin of Science, Technology \& Society, 30(6), 398-414. Doi: 10.1177/0270467610380008

İkiz, O. O., Sobaci, M. Z., Yavuz, N. ve Karkin, N. (2014). Political use of Twitter: The case of metropolitan mayor candidates in 2014 local elections in Turkey. In ICEGOV'14 Proceedings of the 8th International Conference on Theory and Practice of Electronic Governance (s. 41-50). New York: ACM. Doi: 10.1145/2691195.2691219

Jensen, M. J. ve Anstead, N. (2014). Campaigns and social media communications: A look at digital campaigning in the 2010 U.K. general election. B. Grofman, A. H. Trechsel ve M. Franklin (eds). In The Internet and Democracy in Global Perspective (s. 57-81). Cham: Springer. Doi: 10.1007/978-3-319-04352-4_5

Karlsen, R., ve Enjolras, B. (2016). Styles of social media campaigning and influence in a hybrid political communication system. The International Journal of Press/Politics, 21(3), 338-357. Doi:10.1177/1940161216645335

Kemp, S. (2019a). Digital 2019: Q3 Global Digital Statshot. Access address: https:// datareportal.com/reports/digital-2019-q3-global-digital-statshot 
Kemp, S. (2019b). Digital 2019: Global Internet Use Accelerates. Access address: https:// wearesocial.com/blog/2019/01/digital-2019-global-internet-use-accelerates

Kılıçaslan, E. (2016). Siyasal iletişim açısından sosyal medyanın önemi: 7 Haziran ve 1 Kasım seçimleri sürecinde liderlerin Twitter paylaşımlarının söylem analizi çerçevesinde karşılaștırılması. In International Symposium Culture and Communication in Anatolia: Past, Present and Future (s. 147-156). Ankara: Atılım Üniversitesi Yayınları.

Kılıçaslan, E. ve Çalışır, G. (2018). Stratejik siyasal iletişim bağlamında referandumlar 16 Nisan 2017 anayasa değişikliği referandumu Twitter analizi. Karabük Üniversitesi Sosyal Bilimler Enstitüsü Dergisi, 8(2), 468-484. Doi: 10.14230/joiss536

Krippendorff, K. (2004). Content Analysis: An Introduction to Its Methodology (2. Bs.). Thousand Oaks: Sage Publications.

Larsson, O. A. (2018). Small is the new big-at least on Twitter a diachronic study of Twitter use during two regional Norwegian elections. M. Z. Sobaci ve I. Hatipoglu (eds.). in Social Media, Democracy and Politics: Lessons from sub-National Level (s. 169182). Cham: Springer. Doi: 10.1007/978-3-319-73386-9_9

Larsson, O. A. ve Ihlen, $\varnothing$. (2015). Birds of a feather flock together? Party leaders on Twitter during the 2013 Norwegian elections. European Journal of Communication, 30(6), 666-681. Doi: 10.1177/0267323115595525

Lilleker, G. D., Koc-Michalska, K., Schweitzer, E., Johanna, J. M., Jacunski, N. J. ve Thierry, V. (2011). Informing, engaging, mobilizing or interacting: Searching for a European model of web campaigning. European Journal Of Communication, 26(3), 195-213. Doi: $10.1177 / 0267323111416182$

Mirer, M. L., ve Bode, L. (2013). Tweeting in defeat: How candidates concede and claim victory in 140 characters. New Media \& Society, 17(3), 453-469. Doi:10.1177/1461444813505364

Njoroge, R. (2013). Impacts of social media among the youth on behavior change a case study of university students in selected universities in Nairobi, Kenya (Master's t-Thesis, University Of Nairobi, Nairobi). Access address: http://erepository.uonbi. ac.ke/handle/11295/59256

Onat, F. ve Okmeydan, C. K. (2015). Politik halkla ilişkilerde sosyal medya kullanımı: 30 Mart 2014 Yerel Seçimleri ve 10 Ağustos 2014 Cumhurbaşkanlığı Seçimleri. Akdeniz İletişim Dergisi, 23, 79-94. Doi: 10.31123/akil.436870

Örselli, E., Sevinç, İ., Karabulut, N. ve Dinçer, S. (2018). Web 2.0 uygulamalarının seçim çalışmalarındaki yeri: Anayasa referandumu ve Twitter kullanımı. Uluslararası Sosyal Araştırmalar Dergisi, 11(57), 696-713. Doi: 10.17719/jisr.2018.2483

Ramos-Serrano, M., Fernández Gómez, J. D., ve Pineda, A. (2018). 'Follow the closing of the campaign on streaming': The use of Twitter by Spanish political parties during the 2014 European elections. New Media \& Society, 20(1), 122-140. Doi:10.1177/1461444816660730

Silsüpür, Ö. (2016). Siyasal iletişim aracı olarak Twitter'ın kullanımı: 07 Haziran 2015 genel seçimi üzerine bir çalışma. Gümüşhane Üniversitesi İletişim Fakültesi Elektronik Dergisi, 4(2), 725-747. Doi: 10.19145/gujofoc.77651 
Sobaci, M. Z. ve Karkin, N. (2013). The use of Twitter by mayors in Turkey: Tweets for better public services?. Government Information Quarterly, 30, 417-425. Doi: 10.1016/j. giq.2013.05.014

Stier, S., Bleier, A., Lietz, H. ve Strohmaier, M. (2018). Election campaigning on social media: Politicians, audiences, and the mediation of political communication on Facebook and Twitter, Political Communication, 35(1), 50-74. Doi: 10.1080/10584609.2017.1334728

Sukmayadi, V., Suryadi, K., ve Rouf, M. F. (2019, June). Cyberpragmatic Analysis of Indonesian Opposition Politicians' Tweets. In Eleventh Conference on Applied Linguistics (CONAPLIN 2018) (s. 245-249). Amsterdam: Atlantis Press. Doi: 10.2991/conaplin-18.2019.263

Tarai, J. (2019). Social media and Fiji's 2018 national election. Pacific Journalism Review: Te Koakoa, 25(1\&2), 52-64. Doi: 10.24135/pjr.v25i1and2.476

Tongut, S. ve Akman, E. (2014). Sosyal medyanın siyasi partiler tarafından siyasal iletişim aracı olarak kullanılması: 2014 Yerel Seçimleri ve Cumhuriyet Halk Partisi İstanbul Büyükşehir Belediye Başkan adayı Mustafa Sarıgül'ün Twitter kullanımı. International Periodical For The Languages, Literature and History of Turkish or Turkic, 9(5), 117-137. Doi: 10.7827/TurkishStudies.6925

Triantafillidou, A., Lappas, G., Kleftodimos, A. ve Yannas, P. (2018). Attack, interact and mobilize: Twitter communication strategies of Greek Mayors and their effects on users' engagement. M. Z. Sobaci ve I. Hatipoglu (eds.). In Sub-National Democracy and Politics Through Social Media (s. 65-89). Cham: Springer. Doi: 10.1007/978-3319-73386-9_4

Vepsäläinen, T., Li, H., ve Suomi, R. (2017). Facebook likes and public opinion: Predicting the 2015 Finnish parliamentary elections. Government Information Quarterly, 34(3), 524-532. Doi: 10.1016/j.giq.2017.05.004

Vergeer, M., ve Hermans, L. (2013). Campaigning on Twitter: Microblogging and online social networking as campaign tools in the 2010 general elections in the Netherlands. Journal of Computer-Mediated Communication, 18(4), 399-419. Doi:10.1111/ jcc4.12023

Yeniçă̆ (7 Mayıs 2019). 'Her şey çok güzel olacak' sloganı nasıl ortaya çıktı?, Erişim adresi: https://www.yenicaggazetesi.com.tr/her-sey-cok-guzel-olacak-sloganinasil-ortaya-cikti-233260h.htm.

Yılmaz, M. ve Karakaş, O. (2019). 24 Haziran 2018 Cumhurbaşkanlığı seçimlerinin siyasal değerler açısından analizi. Kocaeli Üniversitesi Sosyal Bilimler Dergisi (KOSBED), 37, 145-160. Doi: 10.35343/kosbed.546232 


\title{
Investigation of the Twitter Content of the Candidates from the Perspective of Political Communication in Istanbul Metropolitan Mayoralty Elections
}

\author{
Fatih Çelik (Lect. Ph.D.)
}

\section{Extended Abstract}

Along with the communication technologies that have undergone a great development process in the early 21st century, the effective use of the internet all over the world has affected almost all disciplines. With this digital transformation, which we can call the new 'chimney-free industry', political communication studies have also entered into change and transformation. The political transformation process of political parties and politicians, starting with the website first, continues rapidly with social media platforms such as Facebook, YouTube, Instagram and especially Twitter. Demonstrating its importance and influence in political communication in the 2008 US presidential and 2010 UK elections, Twitter has now become a platform frequently used by both the party and politicians to reach their target audience.

Both in the world and in our country, the transfer of political communication activities to the digital environment through social media platforms such as the Internet and Twitter, and direct communication with the target audience auditions in this environment bring many issues to be investigated. In this process, where traditional election campaigns are now becoming digital election campaigns, Twitter is undoubtedly an important platform for both parties and politicians. From this point on, how to reveal the continuation of political parties and analyzed in terms of political communication of politicians use Twitter and in online environments the struggle they entered the square with competitors due to the number of users increased to Twitter every day in Turkey is important.

Turkey, in a referendum held on April 16, 2017, got into a presidential government system and the history of the system's first presidential and parliamentary election was held on June 24, 2018. In addition, the first local elections of the system were held on March 31, 2019 as alliances as a return or obligation of the new system. Great discussion on the decision to renew on June 23, 2019 by lead and SBE IMM election is seated all Turkey's agenda and both life and everyday has become the subject of traditional and socially most hotly debated in the media. The aim of this study is to analyze the content shared, during the campaign process of 23 June IMM Public Alliance JDP candidate Binali Ylldırım and Nation Alliance RPP candidate Ekrem İmamoğlu from their official Twitter accounts in terms of political communication.

Qualitative content analysis technique was used in the study. The two candidates who entered the Istanbul Metropolitan Municipality as an alliance and received the highest number of votes in 31 March 2019, and the dates of 9 May-22 June 2019, which constitute the most effective period of the election campaign, were determined by purposeful sample management. The content shared by Binali Ylldırım from '@TCMeclisBaskani' until 27 May 2019 and '@BY' after 27 May 2019 and '@ekrem_imamoglu' account of the Ekrem İmamoğlu were collected with Maxqda qualitative data analysis program. In the content analysis process, the categories were determined in accordance with the previous studies and the coding was realized through the Maxqda program. In this study, statistics 
of comparison and relationship analysis and word cloud analysis were performed. In Maxqda qualitative analysis program, the data is first encoded into subcodes and then these codes are categorized and analyzed. 1847 coding for Binali Ylldırım and 1256 coding for Ekrem İmamoğlu were done. In the total study, 3103 coding was done and the data were prepared for analysis.

In the research, when mentioning candidates' responses to other users was taken into consideration, mentioning those labels that were tagged via a straight tweet was not taken into consideration. In addition, flat tweets and quotations shared by the candidates were evaluated in tweet categories, but retweets from other accounts were excluded from the analysis.

According to the findings of the analysis, between May 09 and June 22, 2019, Binali Ylldırım made 518 straight tweets, 11 mention and 12, while Ekrem İmamoğlu shared 1 quote with 354 straight tweets and did not use Twitter's reply feature during this period. Finally, a total of 896 tweets, 541 of Binali Yıldırım and 355 of Ekrem İmamoğlu, were analyzed. Besides, while Ekrem İmamoğlu generally shares daily tweets at a certain level, it is seen that there are fluctuations in the number of tweets of Binali Ylldirım in certain periods. During this period, Binali Ylldırım shared 12 tweets on average, while Ekrem İmamoğlu shared 8 tweets on average. It can be said that Binali Yıldırım, the candidate of the Republic Alliance, used Twitter more actively than his opponent during the election campaign. There was a significant increase in the number of tweets of candidates with the entry to the week of the election.

Tweets in the research were classified by location and activity, election campaign communication, personal message, information and explanation, interpersonal dialogue, communication with selected and appointed persons, and other/unknown categories. In addition, the most frequently used hashtags were determined by the candidates, the relationship between hashtags and tweet categories was examined and the word frequency analyzes of the candidates were performed.

In the study, it was found that while candidates mostly used Twitter for location and activity, election campaign communication, personal message and information and explanation, they did not use Twitter for communication with selected and appointed persons and other/unknown purposes. On the other hand, Ekrem İmamoğlu used hashtag in his tweet with \%49,8 percentage and Binali Ylldırım used hashtag with $30.8 \%$ percentage. In general, the rate of using hashtags in all tweets was $\% 38,3$ in both candidates. In addition, while Ekrem İmamoğlu conducted his election campaign through the hashtag \#HerseyCokGuzelOlacak, Binali Yıldırım more often used \#YineBizYapariz hashtag in his posts. It has been determined that there is an intense relationship between \#YineBizYaparız hashtag belonging to Binali Yıldırım and location and activity category and \#IsEhlininKararMilletin hashtag of Yıldırım which belongs to Yıldırım. In addition, as expected, the two candidates used the word 'Istanbul' most frequently on Twitter posts. The words that candidates generally prefer to use are mostly directed to the election campaign communication category, where they enumerate their actions, promises and criticisms, and to the personal message category that includes content such as wishes, celebrations and commemorations. Finally, in the study as an important finding it is revealed that the candidates do not pay much attention to the interaction feature which is one of the most important benefits of social media. 
While there are many studies on the use of Twitter in the general elections, there is a need for studies on the use of social media in political communication in local elections. Another requirement is that the accounts analyzed during the election campaign periods are not analyzed much in the post-election period when the campaign ends. From this point of view, future studies should be done by comparing the pre-election and postelection periods. In addition, during the March 31 elections and the renewed election, the June 23 elections, the practices of IMM presidential candidates using Twitter or other social media platforms can be examined comparatively by researchers in the future. In addition, a qualitative focus group or interview study or a quantitative survey can be conducted to determine whether the use of social media by IMM presidential candidates affects voter behavior.

Keywords: Political Communication, Twitter, June 23 Istanbul Metropolitan Mayoralty Election, Binali Yıldırım, Ekrem İmamoğlu. 
